Illinois State University

ISU ReD: Research and eData

Theses and Dissertations

$4-12-2019$

\title{
Hydrogeologic Characteristics and Groundwater Sustainability of a Deep Bedrock Aquifer System in Illinois
}

Luis Martinez

Illinois State University, Imarti7@ilstu.edu

Follow this and additional works at: https://ir.library.illinoisstate.edu/etd

Part of the Geology Commons, and the Hydrology Commons

\section{Recommended Citation}

Martinez, Luis, "Hydrogeologic Characteristics and Groundwater Sustainability of a Deep Bedrock Aquifer System in Illinois" (2019). Theses and Dissertations. 1116.

https://ir.library.illinoisstate.edu/etd/1116

This Thesis is brought to you for free and open access by ISU ReD: Research and eData. It has been accepted for inclusion in Theses and Dissertations by an authorized administrator of ISU ReD: Research and eData. For more information, please contact ISUReD@ilstu.edu. 
HYDROGEOLOGIC CHARACTERISTICS AND GROUNDWATER SUSTAINABILITY OF

A DEEP BEDROCK AQUIFER SYSTEM IN ILLINOIS

\section{LUIS MARTINEZ}

77 Pages

Population growth and climate change has made groundwater an increasingly important freshwater resource. This study uses MODFLOW to characterize and estimate sustainable yield of the deep St. Peter Aquifer in Bloomington, IL. Sustainable yield is defined as the maximum amount of water which can be withdrawn from an aquifer. The city of Bloomington has installed two high capacity wells into the St. Peter Sandstone to meet its growing water demands. The St. Peter Aquifer is mostly confined, receiving almost no modern recharge and is experiencing overexploitation in parts of Northern Illinois. I hypothesize that existing fast depletion of the deep St. Peter occurs due to lower-than-expected aquifer parameters of the aquifer. Further, current pumping of groundwater from the St. Peter, plus the new wells could compromise longterm sustainability. The objective of this study is to characterize the aquifer and assess long-term sustainability of this aquifer with projected increases in demand. This study modeled changes in the water level of the St. Peter Aquifer to estimate sustainable yield using MODFLOW. The regional model found that the Sandwich Fault Zone exacerbated the decrease in water level in wells near the fault. Lack of complexity in the regional model caused the model to underperform compared to the Illinois Groundwater Flow Model (IGWFM) developed by the Illinois State Water Survey. Interpolation of the regional model onto the local model showed pumping had no effect on distant wells, so pumping from areas far from the Bloomington has no effect on the its 
wells. Since distant pumping has no effect on distant wells, the local model was set up and calibrated independently of the regional model. Grid refinement was applied to the local model to isolate the effects of pumping wells, making for easier calibration. Once the model was calibrated, an uncertainty analysis showed that hydraulic conductivity was the most sensitive parameter. A prediction model based on projected water demand for the city of Bloomington showed that the well's sustainable yield depends on the aquifer parameters and the pumping rate by the city of Bloomington.

KEYWORDS: Groundwater, Sustainability, MODFLOW, St. Peter Sandstone 
HYDROGEOLOGIC CHARACTERISTICS AND GROUNDWATER SUSTAINABILITY OF

A DEEP BEDROCK AQUIFER SYSTEM IN ILLINOIS

LUIS MARTINEZ

A Thesis Submitted in Partial

Fulfillment of the Requirements

for the Degree of

MASTER OF SCIENCE

Department of Geography, Geology, and the Environment

ILLINOIS STATE UNIVERSITY

2019 
(C) 2019 Luis Martinez 
HYDROGEOLOGIC CHARACTERISTICS AND GROUNDWATER SUSTAINABILITY OF

A DEEP BEDROCK AQUIFER SYSTEM IN ILLINOIS

LUIS MARTINEZ

COMMITTEE MEMBERS:

Wondwosen M. Seyoum, Co-chair

Eric W. Peterson, Co-chair

David Malone 


\section{ACKNOWLEDGMENTS}

This completion of this thesis would not be possible without the support of many people. Firstly, I would like to thank my advisor Dr. Wondwosen Seyoum for his guidance and encouragement during the completion of this thesis. I would like to also thank the other members of my committee, Dr. Eric Peterson and Dr. David Malone whose guidance has made me a better scientist. A thank you to Dr. Daniel Abrams at the Illinois State Water Survey for providing the data and feedback that made this research possible.

I would also like to thank my fellow graduate students in the Hydrogeology program. Thank you all for your advice, feedback, and friendship. A special thank you to Jake Piske and Andrew Oberhelman for putting up with me as a roommate. Another special thank you to Prince Oware for powering through our deficiencies together and as a member of WRESL. Lastly, I would like to thank my family for their moral support throughout my Masters. 


\section{CONTENTS}

Page

ACKNOWLEDGMENTS

$\begin{array}{ll}\text { CONTENTS } & \text { ii }\end{array}$

TABLES

FIGURES

CHAPTER I: INTRODUCTION AND RESEARCH OBJECTIVES 1

Introduction $\quad 1$

$\begin{array}{lr}\text { Hypothesis and Research Objectives } & 6\end{array}$

$\begin{array}{ll}\text { Safe and Sustainable Yield } & 7\end{array}$

$\begin{array}{ll}\text { CHAPTER II: BACKGROUND } & 9\end{array}$

$\begin{array}{ll}\text { Study Area } & 9\end{array}$

$\begin{array}{ll}\text { The Study Area } & 9\end{array}$

$\begin{array}{ll}\text { St. Peter Sandstone } & 12\end{array}$

$\begin{array}{ll}\text { Modeling } & 14\end{array}$

$\begin{array}{ll}\text { Geologic Models } & 14\end{array}$

$\begin{array}{ll}\text { Numerical Groundwater Models } & 14\end{array}$

CHAPTER III: METHODOLOGY 16

$\begin{array}{ll}\text { Data Collection } & 17\end{array}$

$\begin{array}{ll}\text { Geologic Data } & 18\end{array}$

$\begin{array}{ll}\text { Pumping Data } & 19\end{array}$

$\begin{array}{ll}\text { Head Data } & 19\end{array}$

$\begin{array}{ll}\text { Boundary Condition Data } & 20\end{array}$ 
$\begin{array}{ll}\text { River Data } & 20\end{array}$

$\begin{array}{ll}\text { Elevation Data } & 22\end{array}$

$\begin{array}{ll}\text { Data Processing } & 22\end{array}$

$\begin{array}{ll}\text { Geological Model } & 22\end{array}$

$\begin{array}{ll}\text { Groundwater Model } & 25\end{array}$

$\begin{array}{ll}\text { CHAPTER IV: RESULTS } & 47\end{array}$

$\begin{array}{ll}\text { Calibration } & 47\end{array}$

$\begin{array}{ll}\text { Regional Model } & 48\end{array}$

$\begin{array}{ll}\text { Local Model } & 49\end{array}$

Bloomington Pump Test $\quad 51$

$\begin{array}{ll}\text { Calibration } & 51\end{array}$

Uncertainty Analysis $\quad 52$

$\begin{array}{ll}\text { Stochastic Simulation } & 52\end{array}$

Prediction Model

CHAPTER V: DISCUSSION

Calibration and Validation $\quad 55$

Regional Model $\quad 55$

$\begin{array}{ll}\text { Local Model } & 57\end{array}$

Parameter Sensitivity and Uncertainty Analysis $\quad 62$

$\begin{array}{ll}\text { Prediction Model } & 64\end{array}$

Model Gaps and Uncertainties $\quad 66$

$\begin{array}{ll}\text { CHAPTER VI: CONCLUSION } & 68\end{array}$

$\begin{array}{lc}\text { REFERENCES } & 70\end{array}$ 
$\begin{array}{ll}\text { 1. Data Sources } & 17\end{array}$

2. List of hydraulic conductivity zones and associated values for the calibrated regional and local models

3. List of pumping wells used in the regional and local model

4. Observation wells used to calibrate the regional model API number is assigned by the ISGS's ILOIL and ILWATER data base

5. Dimensions of the regional 3-D grid in GMS using the NAD 1983 UTM Zone 16N coordinate system

6. Dimensions of the local 3-D grid

7. Performance measure statistics for the regional model

8. List of observed, computed, and residual heads from the calibrated regional model

9. Statistics from local model using the boundary conditions from the regional model

50

10. List of observed, computed, and residual heads from the calibrated local model

11. Parameters of the Bloomington Pump Test

12. Final statistics for local model with the GR method applied to the Bloomington and Chenoa wells

13. Parameter estimation of hydraulic conductivity and recharge using the stochastic method 


\section{FIGURES}

Figure $\quad$ Page

1. Chloride isochrones in groundwater for the St. Peter Sandstone 5

2. Well log distribution maps 10

3. Cross section of Illinois hydrostratigraphic units 11

4. Geographic distribution of St. Peter Sandstone in the Midwest 13

5. Outline of methodology 17

6. Illinois River and gage station map $\quad 21$

7. Elevation map of model layers 25

8. Regional model boundary conditions 28

9. Local model boundary conditions 29

10. Hydraulic conductivity zone map of the model 32

11. Oblique view and cross sections of regional groundwater model 39

12. Oblique view of 3D mesh grid of localized model 41

13. Planar view of GR method applied around the Bloomington and Chenoa wells 42

14. Planar view of the surrounding 9 grid cells around Bloomington Well 44

15. Distribution map of observation wells 47

16. Hydraulic Conductivity vs. Dynamic Head from the stochastic model run 53

17. Predicted drawdown due to pumping based on the predictive model 54

18. Observed Head vs. Computed Head of the regional model 56

19. Contour map of regional model $\quad 57$

20. Observed Head vs. Computed Head of local model 59

21. Contour map of local model 60

22. Aquifer response to the Bloomington pumping test in meters 64 


\section{CHAPTER I: INTRODUCTION AND RESEARCH OBJECTIVES}

\section{Introduction}

As population continues to grow and climate change makes precipitation events less predictable, groundwater becomes an increasingly important freshwater resource. Currently, Earth's largest sources of freshwater are stored in glaciers and snowpack followed by groundwater. Groundwater is utilized more as a potable water resource than glaciers and snowpack because of groundwater's ease of accessibility and glaciers are located at higher latitude areas with low population densities. Globally almost half of Earth's population depends on groundwater as a source of drinking water, with demand expected to rise as both the climate changes and populations continues to grow (United Nations, 2016). This increase in groundwater demand will increase stress on groundwater resources (Hashemi et al., 2015). As a result, groundwater pumping has increased to meet potable, agricultural, and industrial demands (Custodio, 2002).

Groundwater pumping wells are developed for both public and private water uses. Private wells are generally drilled and operated by people living in rural areas with limited access to municipal sources or surface water or by the industrial sector. About $15 \%$ of the U.S. population relies on private wells for their drinking water, which tend to pump from shallower aquifers due to the high cost of drilling, operating, and maintaining wells (Fox et al., 2016). Private wells are commonly developed by the agricultural sector who use groundwater as a supplement to precipitation and surface water sources (Wilcox et al., 2010). Increases in demand for groundwater has led to drilling of deeper higher capacity wells, over the past century (Church et al., 2013). 
Pumping from deeper aquifers is generally done by public water municipalities that provide year-round potable water for drinking or general domestic use. The public sector or municipalities are able to afford the cost of drilling, operating, and maintain deeper, higher capacity wells. Private wells are drilled and operated by a private individual or business. Private wells can be used for private domestic use or in industry. Both sectors are subject to over extraction, meaning more water is pumped from the aquifer than is being replenished (Custodio, 2002). Excessive groundwater extraction can lead to falling water tables, groundwater storage depletion, quality deterioration, and rising extraction cost associated with falling water tables (Fishman et al., 2011).This is a global issue that needs to be solved at the local level due to the unique characteristics of every aquifer.

In the state of Illinois, $67 \%$ of public water systems use groundwater as a source of potable water resource (Bryant and Meyer, 2010). Illinois water municipalities volumetrically drew $24 \%$ of their water from groundwater sources, which has been increasing over the last decade (Bryant and Meyer, 2010). Although volumetrically groundwater makes up a smaller amount of the total water provided by municipalities on a state level, on a local level groundwater can make up a bigger portion of the water provided by municipalities. This is especially true in areas with limited access to surface water sources or rural areas where it does not make economic sense to connect to district municipal services (Wilcox et al., 2010). Municipalities in central and southern Illinois have been able to mainly rely on surface water sources due to a low population density, presence of sufficient amounts of surface water, and precipitation. Groundwater pumping in central and southern Illinois is limited to shallower aquifers. Municipalities pump water from shallower whereas private farmers use this aquifer to 
supplement irrigation. Pumping from deeper groundwater sources is limited, but is becoming an option for cities such as Bloomington, IL.

The city of Bloomington uses Lakes Evergreen and Bloomington as their primary source of water, but the threat of drought and nitrate pollution necessitated the need for an alternate source of water (Lavaire, 2017, Roadcap et al., 2011). Famers and nearby towns, such as the town of Normal, IL have been pumping from the shallower Mahomet Aquifer for decades (Wilson et al., 2013). The City of Bloomington however decided to install two high capacity wells into the deeper and less contested St. Peter Sandstone aquifer to meet its growing water demands. These new wells will act as a secondary water source during droughts and will be used to dilute the high nitrate concentrated Lake Evergreen and Lake Bloomington water (Abrams et al., 2015).

Bloomington's new pumping wells will be the southernmost wells that pump from the St. Peter Sandstone. Pumping from the St. Peter has historically been restricted to northern Illinois, especially in areas with limited access to water from the Great Lakes. Parts of northern Illinois, such as Will, Kane, and Kendall Counties, are beginning to see problems associated with decades of pumping from the St. Peter (Abrams et al., 2015). In the Aurora, IL area, drawdown exceeds $500 \mathrm{ft}$., and in Joliet, IL the aquifer shows signs of desaturation (Meyer et al., 2009).

Desaturation of an aquifer is when the pore space within an aquifer is not completely filled with water, which can be caused when groundwater leaving the aquifer exceeds the amount of water coming into the aquifer. The elevation of the saturated zone is known as the water level or hydraulic head. Head of an aquifer is a function of the pressure head, elevation head, and velocity head. A decrease in head or the water level is known as drawdown. Increased pumping rates causes can lead to drawdown of the water level and to desaturation of the aquifer. Increases 
in drawdown can lead to increases in pumping cost and decreases in water quality as pumping pulls saline waters up from the deeper aquifer.

There is little interest in pumping water from the St. Peter Aquifer in the Bloomington area due to the increased depth of the St. Peter in central Illinois. The increased depth leads to higher pumping cost which deters pumping from the St. Peter Aquifer in this area. This increased depth and lack of recharge into the St. Peter also leads to increases in salinity. This leads to salinity concentrations over $5000 \mathrm{mg} / \mathrm{L}$ south of Bloomington (Panno et al., 2017) as seen in Figure 1.

The question is whether the pumping by the City of Bloomington have similar results as Aurora and Joliet and cause the St. Peter Aquifer to become desaturated? The focus on this research is to assess long-term sustainability of pumping water from Bloomington's new wells screened within the St. Peter Aquifer. 


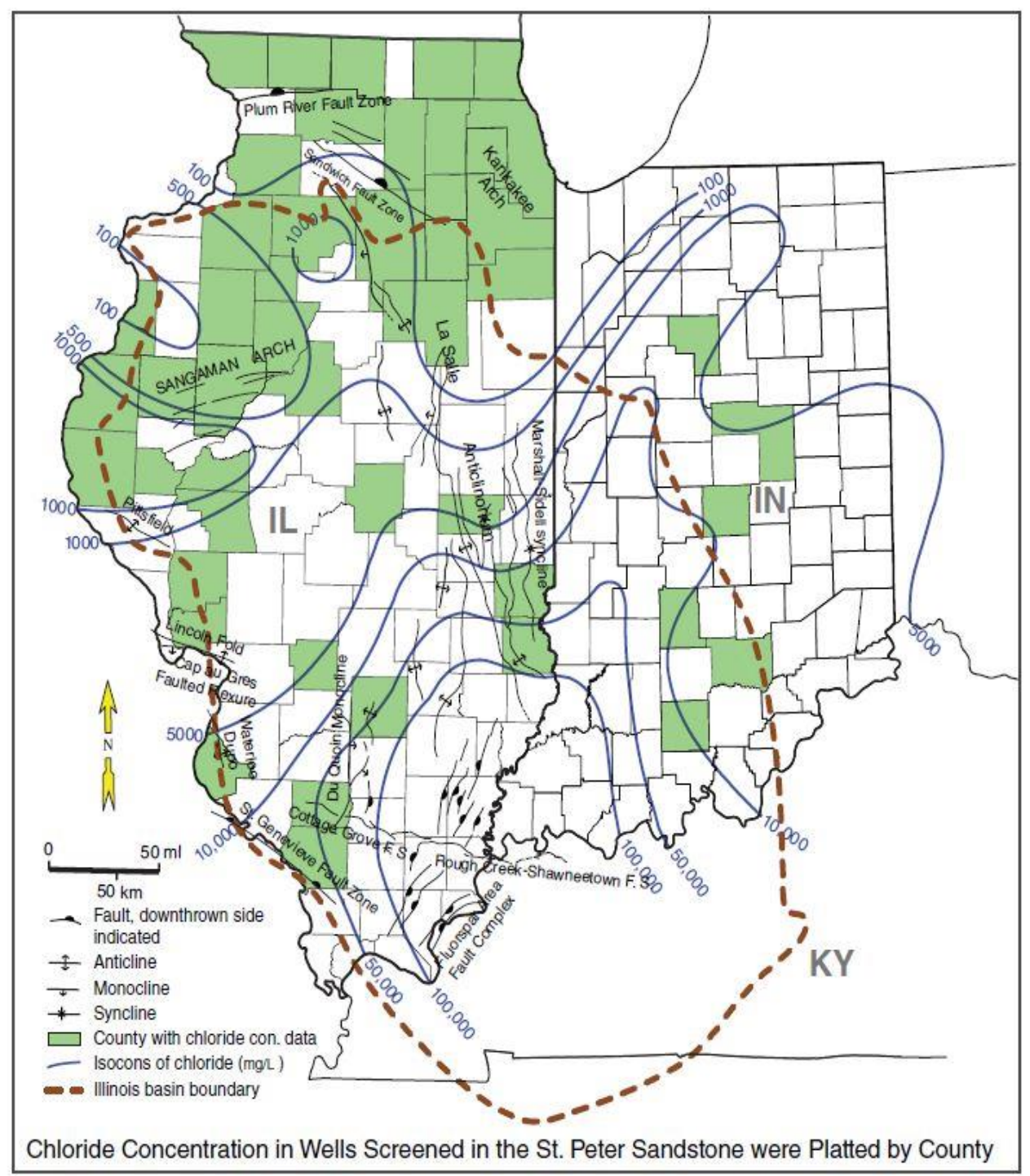

Figure 1. Chloride isochrones in groundwater for the St. Peter Sandstone. From Panno et al., 2017. Water quality datum are from groundwater samples from wells screened in the St. Peter Sandstone. All concentrations are from published data and were plotted by county.

Pumping rates are affected by total demand from the city and by changes in water quality and quantity in Lakes Evergreen and Bloomington. Climate projections show increases in runoff in McLean County, which can lead to increases in nitrate loading into the Lakes Evergreen and Bloomington reducing water quality (Honings, 2018). The increase in nitrate loading into these lakes will lead to increased pumping from the St. Peter in order to dilute the high nitrate rich 
water from the lakes. Total demand by the people of Bloomington also affects how much water will be pumped from the St. Peter. With the population expected to increase of the next few decades, more water will need to be pumped in order to meet increasing water demand. Projected water demand by Bloomington, IL was based on Bloomington's 2010 Interim Water Plan (http://www.cityblm.org/home/showdocument?id=4192).

This study will assess long-term sustainability of Bloomington's new wells by modeling changes in head within the St. Peter Aquifer by estimating sustainable yield. Measuring change in hydraulic head is important because as explained above, changes in head affect pumping cost and water quality.

\section{Hypothesis and Research Objectives}

This study will model changes in the potentiometric surface of the St. Peter Sandstone aquifer to determine its long-term sustainability. This study will mainly focus on the proposed groundwater wells by the city of Bloomington near the city, but will also consider the effects of

pumping from nearby cities like Chenoa, IL on the St. Peter Aquifer. This will better characterize the aquifer and provide more calibration data. I hypothesize that existing depletion of the deep St. Peter occurs due to lower-than-expected aquifer parameters such as hydraulic conductivity (K) of the aquifer. Lower hydraulic conductivity does not allow for water to flow into the well as quickly which leads to a drop in head. Further, current pumping of groundwater from the St. Peter, plus the new wells could compromise long-term sustainability. Long term sustainability will be evaluated by estimating sustainable yield of the St. Peter Aquifer. Large withdrawals, low recharge rates, and low hydraulic conductivity can lead to higher drops in head, which can cause significant drops in head and desaturation like in Joliet and Aurora, IL (Abrams et al., 2015). 


\section{Research Questions}

1. Are the characteristics (e.g., K) of the St. Peter Aquifer determinant in the potential of the aquifer as well as its future sustainability?

2. Does the addition of the two wells by Bloomington into the St. Peter Aquifer satisfy the increase in projected water demand and future water-quality problems without exceeding its sustainable yield?

When considering future increases in water demand and sustainable use of groundwater resources, it has become imperative to understand the dynamics of the groundwater flow system and its hydrogeologic characteristics (Pandey and Kazama, 2011). This paper aims to accomplish this by creating a geologic and a groundwater model of the area. The goals of the research are to:

1. Characterize aquifer parameters (e.g. K) of the St. Peter Aquifer.

2. Assess long-term sustainability of the St. Peter Aquifer by estimating sustainable yield of the aquifer from pumping by the city of Bloomington, IL.

\section{Safe and Sustainable Yield}

There have been multiple studies looking into safe and sustainable yield, all which define these terms differently (Roman et al., 2010, Kalf and Donald, 2005). These two terms are used interchangeably with no one true definition. For this study the term sustainable yield will be used. Definitions generally relate the rate of which groundwater can be withdrawn before resulting in an undesirable result such as a reduction in water quality or desaturation of the aquifer. In this study the undesirable result is desaturation of the St. Peter aquifer from pumping by Bloomington, IL. Other definitions of sustainable yield state that the pumping rate should equal the recharge rate. In this study since recharge is minimal, the concept of achieving a sustainable yield in which the pumping rate is below or equal to the recharge rate is questionable. 
Pumping from a confined aquifer like this with minimal recharge is basically a mining venture (Kalf and Donald, 2005). For this reason, I chose to define sustainable yield as the amount of water that can be pumped before desaturation of the St. Peter Aquifer occurs. 


\section{CHAPTER II: BACKGROUND}

\section{Study Area}

\section{The Study Area}

Bloomington IL, is a developed suburban area surrounded by tile-drained agricultural fields. The area is classified as a humid continental climate, characterized by large seasonal temperature differences with warm humid summers and cold winters (Peel et al., 2007). The area is at an elevation of $252 \mathrm{~m}$ above sea level (Peel et al., 2007).

This study focuses on a deep Ordovician aquifer system in Illinois providing water for parts of the state. The study area is shown in Figure 2. The St. Peter Sandstone is overlain by Galena-Platteville Carbonate, Maquoketa Shale, Silurian Carbonate, PennsylvanianMississippian Shale, with Glacial Deposits on the surface (Figure 3). The overlying Maquoketa Shales and Pennsylvanian Shale acts an aquitard preventing water from the surface from reaching the St. Peter Aquifer. The St. Peter Sandstone is underlain by Prarie du Chien Carbonate and Potosi-Franconia Carbonate. This layer is also acts as an aquifer, making the St. Peter an isolated aquifer in this study. 


\section{Well Log Distribribution}

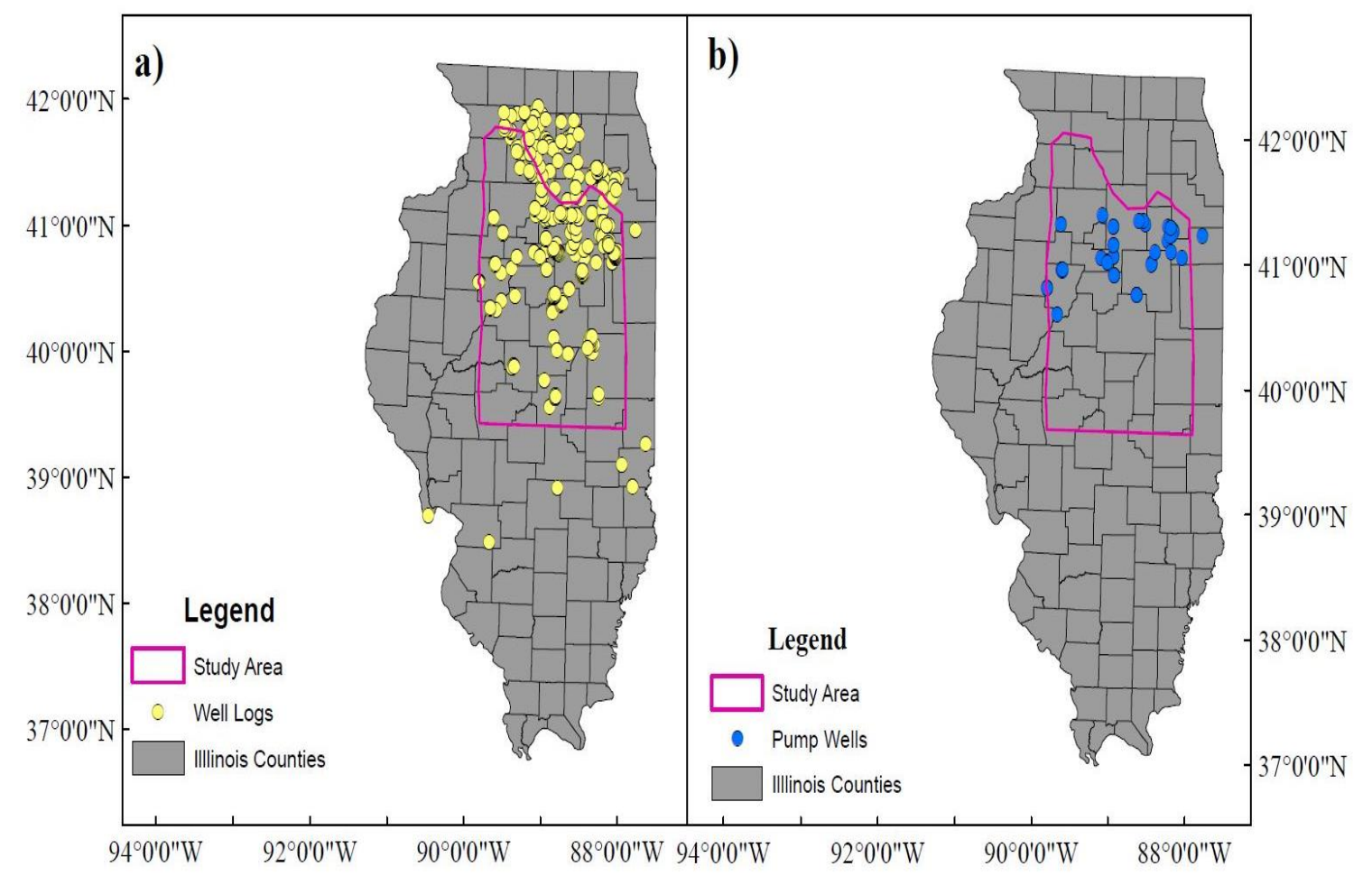

Figure 2. Well log distribution maps. Maps show (a) distribution of well logs in Illinois that contain the St. Peter Sandstone and (b) wells that pump from the St. Peter Sandstone. 


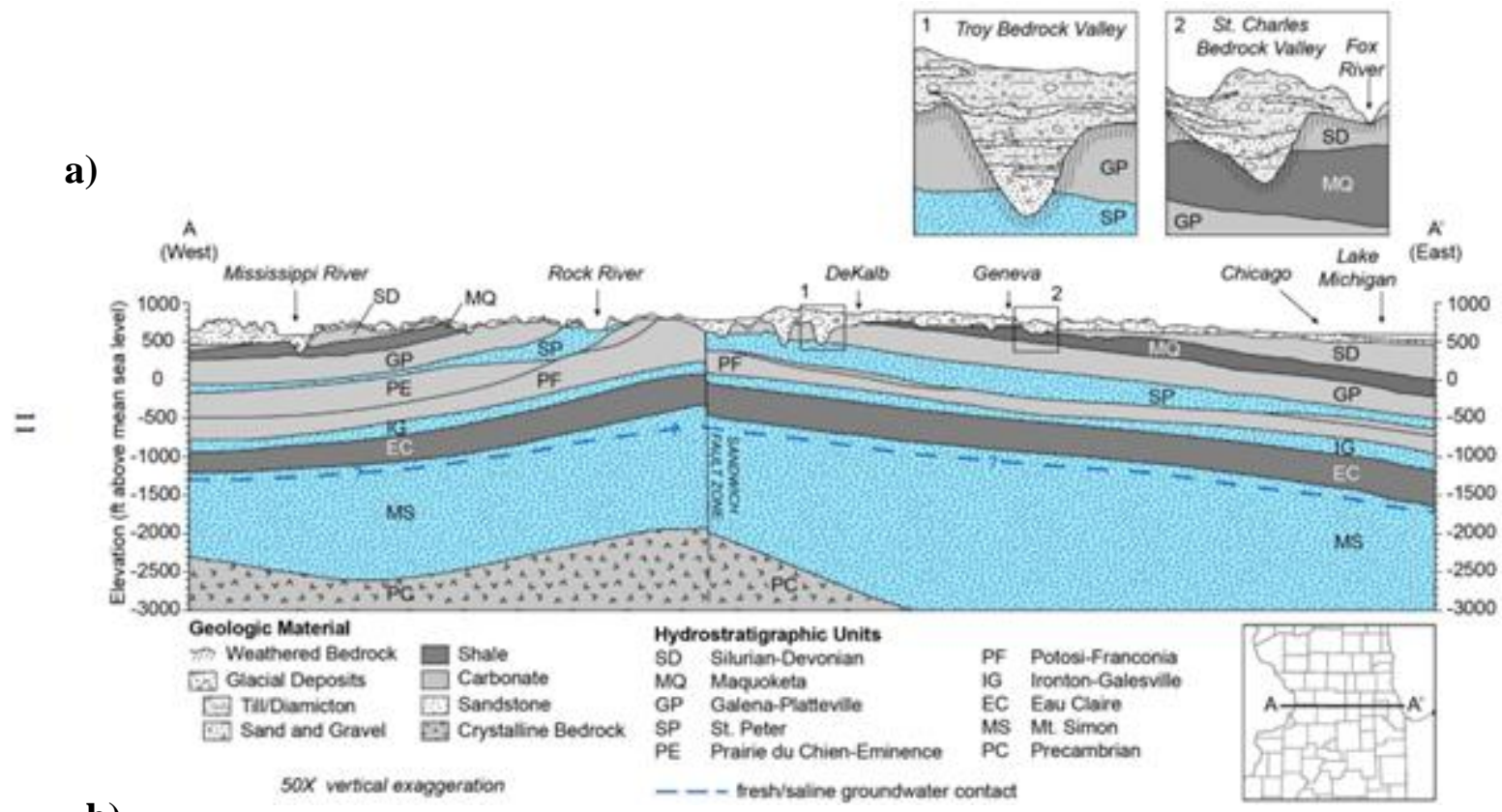

b)

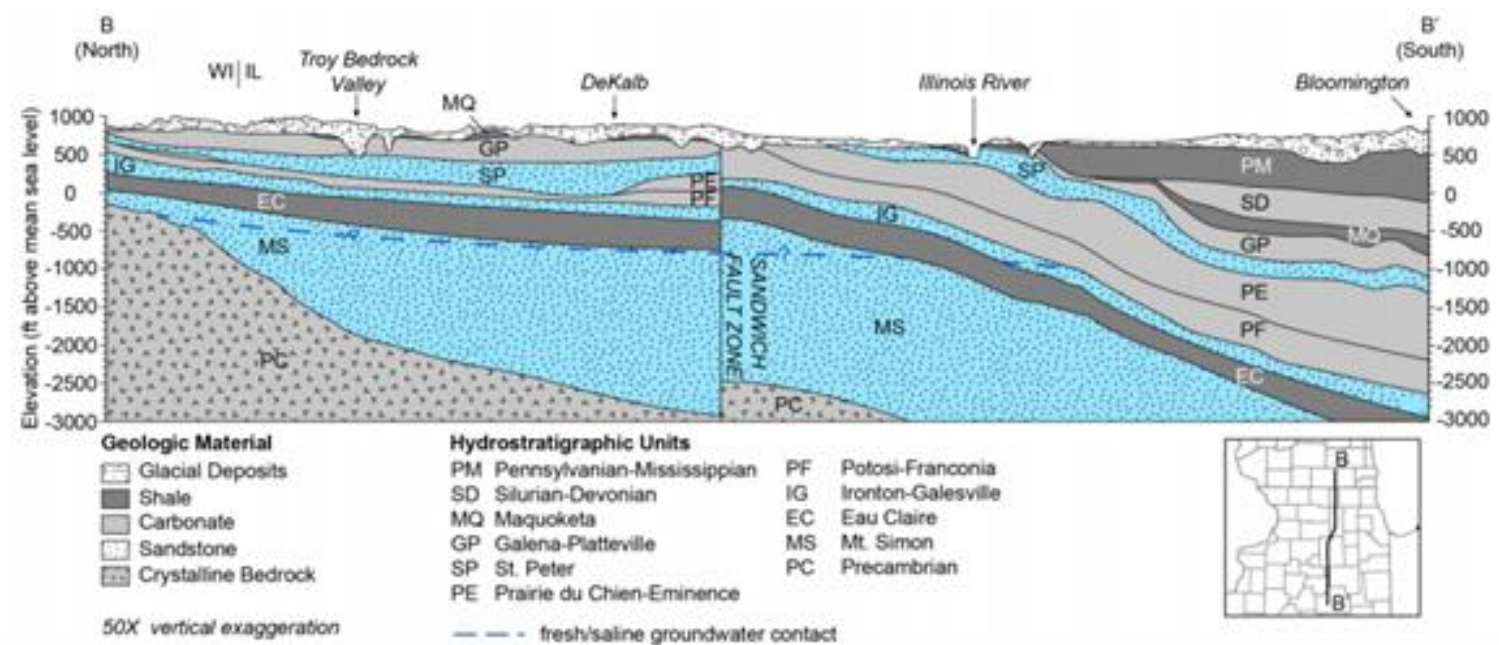

Figure 3. Cross section of Illinois hydrostratigraphic units. From Roadcap et al., 2011. a) Westto-east cross section across northern Illinois from the Mississippi River to Lake Michigan showing the hydrostratigraphic units of the study area. The Troy Bedrock Valley and the St. Charles Bedrock Valley are shown, illustrating the hydrologic connection between glacial sand and gravel aquifers and deeper bedrock aquifers. b) North-to-south cross section from southern Wisconsin to central Illinois showing the hydrostratigraphic units of the study area. 


\section{St. Peter Sandstone}

The St. Peter Sandstone is Middle Ordovician in age covering $576,000 \mathrm{~km}^{2}$ of North America and composes much of the Ancell Unit found in Illinois (Dittes and Labuz, 2002). The extent of the St. Peter Sandstone can be seen in Figure 4. The St. Peter Sandstone is a quartz arenite, varying in thickness from tens of meters to 200 meters. The aquifer is homogeneous and anisotropic (Abrams et al., 2018). The St. Peter was deposited during a sea level rise of the Tippecanoe transgression (Theil, 1935, Konstantinou et al., 2014). Cambro-Ordovician sediment found in the St. Peter was transported to the midcontinent by two early Paleozoic river systems that sourced from the paleo-east (Huron basin) and paleo-northeast (Konstantinou et al., 2014).

Much of the St. Peter is below the surface and is a mostly confined aquifer overlain by the Maquoketa Shale and Pennsylvanian-Mississippian Carbonate Units (Abrams et al., 2015). As a mostly confined aquifer, the St. Peter receives little to no recharge from the surface. The St. Peter is labeled as a mostly confined aquifer because it does outcrop in LaSalle County along the Illinois River, where some recharge can occur. Though the St. Peter receives low recharge from the surface, it is hypothesized that there is inflow of water into the aquifer as a result of leakage from surrounding units (Abrams et al., 2015). The St. Peter dips southward toward the center of Illinois increasing in depth as you move south, lying over $1500 \mathrm{ft}$. (460 m) below the city of Bloomington, IL (Kolata and Nimz, 2010).

Geochemical analysis of water from the St. Peter showed that much of the water is much older than aquifers above it, suggesting that the waters are associated with the burial of the St. Peter Sandstone (Pitman et al., 1997). Panno et al. (2017) observed increased chloride concentration as the St. Peter increased in depth towards central and southern Illinois. The increased chloride concentrations are an indicator of older water and a lack of modern recharge. 
There have been previous studies on the St. Peter Aquifer, but most of those studies have been limited to northeastern Illinois and southern Wisconsin (Abrams et al., 2018; Abrams et al., 2015; Panno et al., 2017). Previous research on groundwater in Illinois has mainly been conducted by the ISWS. One of their studies by Abrams et al. (2018) developed the Illinois GroundWater Flow Model (IGWFM). The IGWFM focused on the Cambrian-Ordovician as a whole. Pumping from the St. Peter in northern Illinois and southern Wisconsin is common because of proximity of the aquifer to the surface (Figure 3 and Figure 4). Since the St. Peter aquifer is significantly deeper under Bloomington (460 m) compared to in La Salle County (150 m) which means that changes in head and pumping expenses can become exacerbated if the unit becomes desaturated.

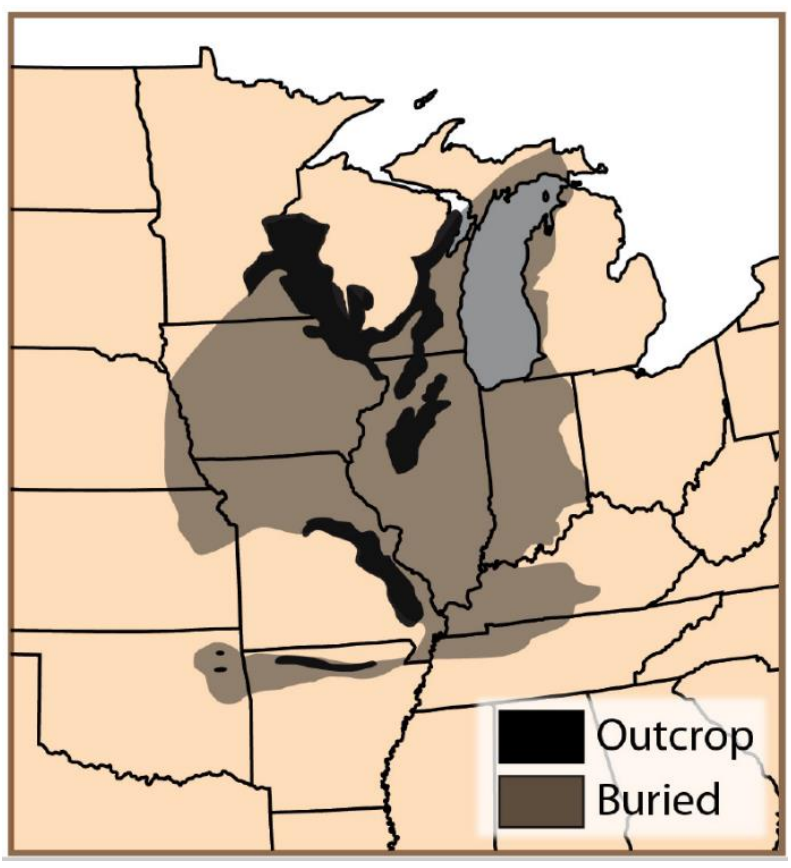

Figure 4. Geographic distribution of St. Peter Sandstone in the Midwest. From the Arizona Geological Survey, adapted from Drake, 1921. Width of the outcrop is exaggerated. 


\section{Modeling}

A model is a simplification of the complex natural world, often in an attempt to replicate natural phenomena. This study develops geological and groundwater models to answer our research questions. The geologic model is used to represent the spatial distribution of our area and helps develop the groundwater model. Groundwater modeling is often used in predictions for the future. The uses of predictive modeling include tracking of a contaminant plume or in our case the sustainability of a well. A predictive groundwater model is often calibrated, but not a true representation of the groundwater system, leaving some uncertainty from its prediction based from errors in the model parameters (Anderson et al., 2015).

\section{Geologic Models}

Representation of geologic features is often in the form of geologic maps and cross sections. The limitation with representing geology in these forms is that they are a twodimensional representation of a three-dimensional (3D) feature and subject to distortion leading to misrepresentation. Geologic models allow for a three-dimensional representation of the system that geology maps and cross sections can lack. The geological model in this study uses existing geological maps supplemented by well log data to recreate the 3D geologic geometry of the study area. The goal of the geologic model is represent the geologic features in the system as seen in Figure 3. The features that our model should show are outcropping of the St. Peter Sandstone in LaSalle County near Starved Rock State Park and increase in depth as you move south towards Bloomington.

\section{Numerical Groundwater Models}

Groundwater simulation models have emerged as powerful tools for addressing complex real world issues concerning impacts of extensive groundwater development (Sahoo and Jha, 
2017). Groundwater modeling is used globally to characterize aquifers, make predictions, and help in water management decisions. Several codes (e.g. MODFLOW, FEFLOW) have been developed and used to simulate groundwater models. MODFLOW, a modular three-dimensional, numerical groundwater modeling software developed by the USGS that uses the finite-difference method (Equation 1) to solve the governing equation for groundwater flow and changes in potentiometric surface (USGS, 2018). A finite difference method is a mathematical technique that divides the aquifer into a grid of blocks to solve equations representing groundwater flow and head (Meyer et al., 2009; Siarkos and Latinopoulos, 2012).

$$
\frac{\partial}{\partial x}\left(K_{x} \frac{\partial h}{\partial x}\right)+\frac{\partial}{\partial y}\left(K_{y} \frac{\partial h}{\partial y}\right)+\frac{\partial}{\partial z}\left(K_{z} \frac{\partial h}{\partial z}\right)+R=S \frac{\partial h}{\partial t}
$$

Equation 1: The mathematical equation for 3D movement of groundwater through a heterogeneous and anisotropic porous media with sources and sinks is described by the partial differential equation. Where $\mathrm{K}$ is the hydraulic conductivity and the subscripts represent anisotropy in direction $\mathrm{x}, \mathrm{y}$, and $\mathrm{z} ; \mathrm{R}$ is sources and sinks; $\mathrm{S}$ is specific storage; $\mathrm{t}$ is time; and $\mathrm{h}$ is hydraulic head. The solution to this governing equation is the hydraulic head in space and time

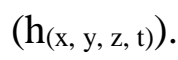




\section{CHAPTER III: METHODOLOGY}

This methodology of the groundwater model follows three basic steps (Figure 5), which are:

1. Model Design

2. Model Calibration

3. Results from the Model Run

The model design includes building a conceptual model followed by construction of the actual groundwater model. This step requires the input of a variety of data. After developing the model, step 2 involves calibrating the model. Model calibration is the comparison of the model results against in-situ data. The in-situ data used in this study are observed heads values from different wells provided by the ISWS. Calibration of the model is done until the error of your model is minimal, meaning that the outputs of the model match well with in-situ observations. Once the error is reduced then you have results from the model (step 3). Step 3 also involves validating, analyzing, and interpreting the final results of the model. 


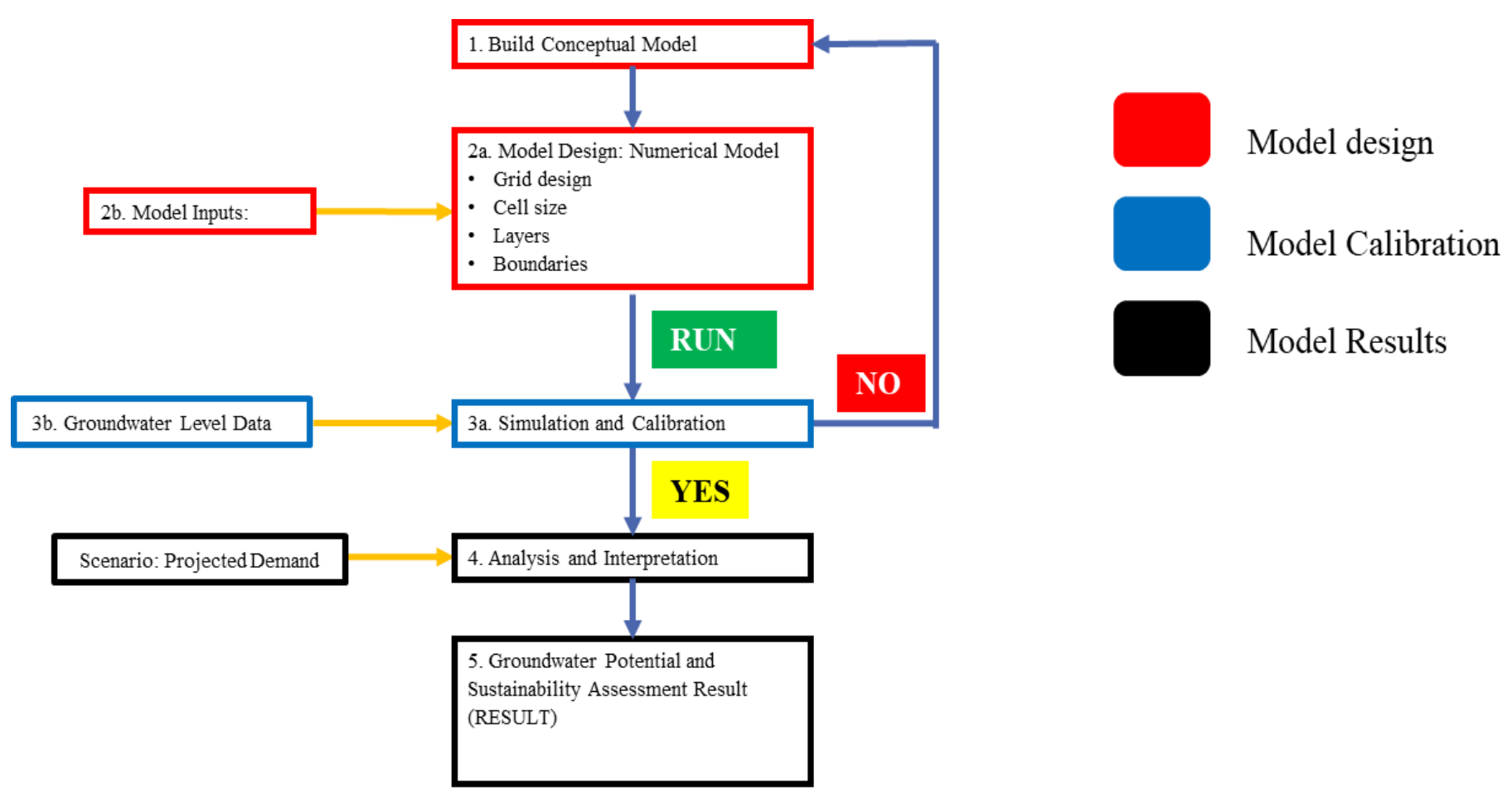

Figure 5. Outline of methodology.

\section{Data Collection}

In order to model groundwater processes, data such as: geologic, pumping, water level (head), river, and elevation. The data used in this study came from a variety of sources as seen in Table 1. These data were used in the creation of both the geologic model and the groundwater model.

Table 1. Data Sources.

\begin{tabular}{|c|c|}
\hline Data & Source \\
\hline Geologic & Illinois Sate Geological Survey \\
\hline Pumping & Illinois State Water Survey \\
\hline Head (water level) & Illinois State Water Survey \\
\hline Structure & $\begin{array}{c}\text { Illinois State Geological Survey } \\
\text { Clearinghouse Database }\end{array}$ \\
\hline River & USGS \\
\hline Elevation & USGS \\
\hline
\end{tabular}




\section{Geologic Data}

Geologic data were taken from the Illinois State Geologic Survey’s (ISGS) Illinois Water and Related Wells (ILWATER) (http://isgs.illinois.edu/ilwater) and Illinois Oil and Gas Resources (ILOIL) (http://www.isgs.illinois.edu/illinois-oil-and-gas-resources-interactive-map) databases. These databases provided information on well logs throughout the state, which included private water wells, public water wells, engineering borings, and stratigraphic borings. Well log information from ILWATER and ILOIL were used to construct a geologic map of the St. Peter Sandstone to determine spatial distribution, thickness, and elevation of the St. Peter. Well log records included the well's georeferenced location, elevation of the well, depth to each lithology in feet, and well type. Well log datum was taken only from well logs that included the top of St. Peter Sandstone. The eastern and western boundaries were determined by the availability of wells that provided geologic datum of the bottom of the St. Peter Sandstone. Distribution of these wells can be found in Figure 2.

Additional well log datum were provided by Daniel Byers of the ISGS. These well logs contained geologic datum from the Illinois Industrial Carbon Capture and Storage project located in Decatur, Illinois. These logs were useful in extending top and bottom elevations of the St. Peter Sandstone south of McLean County. The additional wells also helped in reducing pinching out and thinning of the St. Peter Sandstone when interpolated in ArcMap. This was useful when cross-referencing with previous studies on distribution of the St. Peter where it shows that it does not thin in central and southern Illinois. Interpolation of the St. Peter south of McLean County is important because of the increase in chloride concentration south of McLean County (Panno et al., 2017). The high chloride water causes a density difference between freshwaters in northern 
and saline waters in southern Illinois. This density difference hinders flow between the water, acting as a no flow boundary in the model.

\section{Pumping Data}

Since well logs included well type, any well identified as a municipal water well was used to look for pumping and head datum. Once all water wells were identified, water level and pumping datum were taken from the ISWS for all municipal pumping wells since they have the biggest impact on the aquifer. Pumping rates from private or industrial water wells were not used for this study due to inaccessibility to data and minuscule effect of private well pumping on the aquifer. Pump datum from municipal wells were taken from the ISWS's Illinois Groundwater

Resources server

(https://univofillinois.maps.arcgis.com/apps/webappviewer/index.html?id=53380686a48d43758

3155052fc49d117), which is collected by the ISWS using paper questionnaires (Headly and Hlinka, 2012). Pumping rates for the 2013 year were used for the study. Distribution of the pump wells can be found in Figure 2 .

\section{Head Data}

Groundwater level datum was needed for calibration in order to compare the computed head values from the model to in-situ head values for that year. Water level datum from municipal wells were provided by the ISWS. The ISWS provided a list of head datum from municipal wells in Sandstone wells in Illinois. A total of 21 in-situ observation wells were used in this study. Head datum were also extracted from IGWFM to better calibrate our local model by creating a series of 6 pseudo observations wells. 
In the calibration process, the observation points are weighted differently depending if the observed point was in-situ datum or from the IGWFM. In-situ wells were given a 90\% confidence interval whereas the pseudo observation wells were given a $10 \%$ confidence interval.

\section{Boundary Condition Data}

Boundaries are needed in groundwater modeling to delineate where water flows with our study area. This model used two types of boundary conditions, specified head and no flow. Specified head boundary conditions are implemented by fixing head values at 2 nodes with heads values interpolated along the arc in between the two nodes (Anderson et al., 2015). Head values on the specified head boundary do not change over time.

These boundaries are based on the real hydrogeological system. The presence of a fault zone and thinning of the St. Peter Sandstone along the northern boundary of the study area necessitated the need for a no-flow boundary. This is because the fault zone offsets the St. Peter Aquifer and other lithologies north of the fault zone hindering flow. Structural datum was taken from the ISGS's Geospatial Data Clearinghouse Database (https://clearinghouse.isgs.illinois.edu/frontpage) as shapefiles, in order to be imported into ArcMap and GMS. Both fault and anticline datum were taken to assess their effect on the area, specifically the Sandwich Fault zone. The Sandwich Fault Zone acted as the northern boundary in the regional model.

\section{River Data}

The only river in our study area to be in contact with the St. Peter is the Illinois River (Figure 6). The amount of recharge from the Illinois River into the St. Peter is unknown, but was added to the model because the Illinois River does come in contact with the St. Peter in the northern section of the study area. Illinois River discharge datum was obtained from the USGS's 
National Water Information System Web interface (https://waterdata.usgs.gov/nwis). A total of six stations were identified along the Illinois River in the State of Illinois from the interface, which includes: Copperas Creek, Hardin, Henry, Kingston Mines, Seneca, and Valley City. Data from USGS gages included information onstage height conductance, and bottom elevations of the Illinois River. This information was applied to the river and was designated as a river boundary.

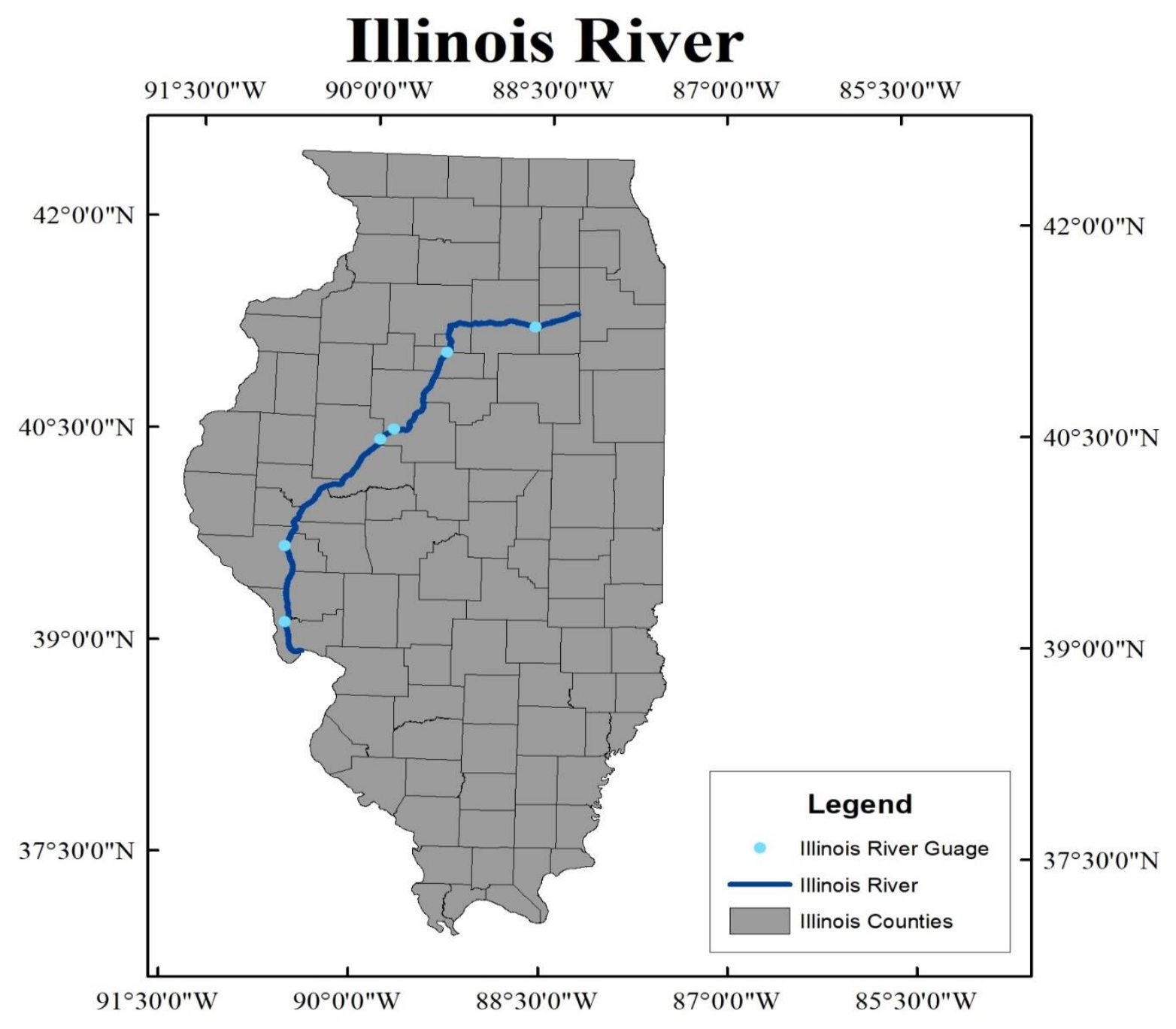

Figure 6. Illinois River and gage station map. Data taken from USGS's National Water Information System Web interface: https://waterdata.usgs.gov/nwis 


\section{Elevation Data}

A Digital Elevation Model (DEM) was downloaded to determine the top and bottom elevation of each layer in our model. The DEM was taken from Advanced Spaceborn Thermal Emission and Refection Radiometer's (ASTER) LP DAAC Global Data Explorer tool (https://gdex.cr.usgs.gov/gdex/). We selected the ASTER Global DEM V2 Map Layer data Coverage. Using the Global Data Explorer tool, we defined an area using the polygon area tool and downloaded 4 areas as Tagged Image Files (TIFs) files due to the large area coverage. These TIFS were combined to make a single TIF file for the entire study area.

\section{Data Processing}

\section{Geological Model}

Geologic datum taken from the ISGS's well log databases (ILOIL and ILWATER) were used to construct three dimensional, geologic model of the St. Peter Sandstone and the surrounding units. All well logs that included the St. Peter Sandstone were added to an excel spreadsheet distinguished by its unique API identification number. Each well log also gave the wells location, well type, and geologic information. Geologic datum was then separated into 3 categories based on hydrogeological characteristics rather than lithology or rock type.

The top layer (Layer 1) of the model consisted of all of the overlying geologic units above the St. Peter Sandstone. All of the overlying layers were lumped together to act as an overlying aquitard in our groundwater model. This was done under the assumption that negligible amounts of recharge are reaching the St. Peter from the surface. The second layer in the model (Layer 2) was the St. Peter Sandstone acting as the main aquifer of the model, about $70 \mathrm{~m}$ thick in the Bloomington area. The third layer (Layer 3) of the model are the rock units below the St. Peter and acted as a lumped basal aquitard. 
Lithological information for each layer was input into ArcMap from the Excel spreadsheet after they were separated. The data was imported into ArcMap as XY data using the North American Datum (NAD) 1983 Geographic Coordinate System (GCS) datum based on the wells location from the well log. The text file was then exported into a shapefile in order to be interpolated into top and bottom elevations and layer thickness in ArcMap. Everything was converted into the NAD 1983 UTM Zone 16N georeferenced datum.

Before interpolation could be done, each well log and each layer needed an associated elevation in meters. Then the 4 DEMs taken from ASTER were merged together in ArcMap using the Mosaic to New Raster tool to create a single DEM that covered the entire study area. Each well log was given an elevation in meters based on the newly stitched DEM using the Extract Multi Values to Points tool. The Extract Multi Values to Points tool works by extracting cell values from a raster at specified locations in a point feature class and record the values from the raster to the attribute table of the point featured class.

Since the log depths were measure in feet, a new field was added to the attribute table in ArcMap, and then converted the well log depths into meters using the field calculator. The elevation of each layer was then calculated by subtracting the wells newly estimated extracted elevation (m) from the depth to each respective layer in meters. Once the tops and bottoms of each layer were calculated, interpolation was done across the study area.

The top and bottom of every layer were interpolated across the area using the Inverse Distance Weighted (IDW) tool under the Spatial Analyst Tools. IWD works by predicting a value for any unmeasured location using the measured values from surrounding locations, in this case the elevation of each layer in our model. Those measured values closest to the prediction 
location will have more influence on the predicted value than those farther away (Johnston et al., 2004). The general formula is:

$$
\hat{Z}\left(s_{0}\right)=\sum_{i=1}^{N} \lambda_{i} Z\left(s_{i}\right)(2)
$$

Where $\mathrm{Z}\left(\mathrm{s}_{0}\right)$ is the value we are trying to predict for location $\mathrm{s}_{0} . \mathrm{N}$ is the number of the measured sample points surrounding the prediction location that will be used in the predication. $\lambda_{\mathrm{i}}$ are the weights assigned to each measure point that we are going to use, $\mathrm{Z}\left(\mathrm{S}_{\mathrm{i}}\right)$ is the observed value at the location $\mathrm{S}_{\mathrm{i}}$. The output feature class was saved as TIF files, one for each of the three layers used in our model. The resulting elevation TIFs for leach layer in the model can be found in Figure 7. 


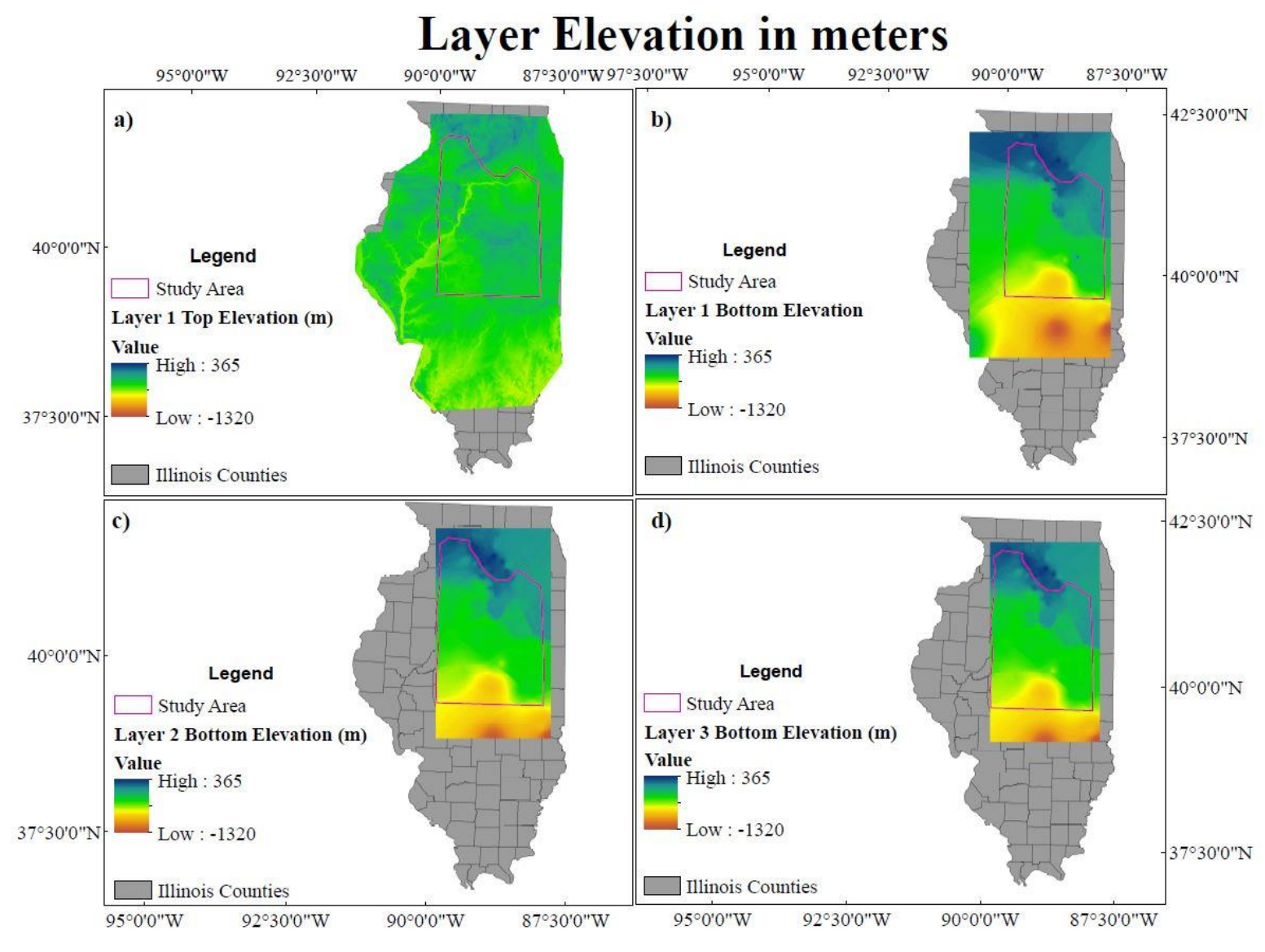

Figure 7. Elevation map of model layers a) Elevation of top of Layer 1. Data from USGS's Global Data Explorer Tool: ASTER Global DEM V2. b) Interpolated elevation of Layer 1 bottom. c) Interpolated elevation of Layer 2 bottom. d) Interpolated elevation of Layer 3 bottom. Data for Figure 7 b-d based on data from ISGS's ILOIL and ILWATER databases.

\section{Groundwater Model}

This study uses Aquaveo’s Groundwater Modeling System (GMS), a Graphical User Interface (GUI) to design the groundwater model. GMS is a GUI developed by Aquaveo that runs MODFLOW and can incorporate GIS data to build the model.

To build the groundwater model in GMS, first, a conceptual model was developed. The conceptual model is just a simplified version of the groundwater model, outlining a different attribute in the groundwater system. The attributes used in the conceptual model are the 
hydrostratigraphic units, boundary conditions, model boundaries, river boundaries, model parameters (Hydraulic Conductivity (K), Recharge), Pumping (Q), and Observation well data.

The groundwater models in this study are steady-state models, meaning that the groundwater model only models one timeframe, which in our case is a day. In this study, we develop two models at two different scales. One model looks at the groundwater system at a larger regional scale. The other looks at the system on a local scale and is based off of the regional model. In order to interpolate the regional model onto the local model, this study used the Grid Refinement (GR) method, which simulates in detail subareas of previously developed regional models (Clark et al., 2010). GR methods work well in situations where the better resolution of the locally refined grid has little influence on the overall flow-system dynamics (Mehl and Hill, 2002). The GR method involves creating a smaller, more refined model for a sub-region of the larger flow model by first simulating the coarse grid and using its results to interpolate heads and fluxes, or a combination of both, onto the boundaries of the local grid (Mehl et al., 2006).

\section{Conceptual Model}

The first step in building a groundwater model is to build a conceptual model. A conceptual model is the composite of what is known about the study area (Kresic and Mikszewski, 2012). GMS has a built in function to build a conceptual model and can incorporate GIS files. Well locations were added as a shapefile into GMS and then added to the conceptual model using the Shape to Feature Objects tool. This tool converts GIS vector data to feature objects (points, arcs, polygons) in the conceptual model. The conceptual model needs different coverages. The first coverage was the boundary coverage of the model, followed by creating 
boundary files for a river boundary, sources and Sinks, and hydraulic conductivity and recharge zones.

\section{Regional Boundary of the Study Area}

The regional boundary of the study area for this conceptual model was based on structural features and data availability. The Southern, Western and Eastern boundaries of the model were limited by data availability. Though data are limited in these directions, they are far away from Bloomington's new wells that we assume they will have little influence on the new wells. The Northern Boundary of the study area was limited by a structural feature. In this case, the structural feature is the Sandwich Fault Zone, which offsets the St. Peter Sandstone hindering flow north of the faults zone as seen in Figure 3.

\section{Boundary Condition}

Groundwater flow in an aquifer system is governed by boundary conditions of the regional system (Psarropoulou and Karatzas, 2017). In groundwater modeling, there are different types of boundary conditions. In this study, the types of boundary conditions used are specified head, river boundary, and no-flow boundary. A specified head boundary has defines head at 2 nodes with GMS interpolating head in between the two nodes. Specified head boundaries for the regional and local model can be found in Figures 8 and 9 respectively. These head values were based on the calibrated IGWFM.

The northern and southern boundaries were designated as no flow boundaries in the regional model, meaning that water does not flow across that boundary line. The northern boundary was designated as a no flow boundaries because of the presence of the Sandwich Fault Zone in northern Illinois. The southern boundary is considered a no flow boundary by the assumption of the presence of brine water interface. Salinity in the St. Peter Sandstone drastically 
increases from about $100 \mathrm{mg} / \mathrm{L}$ to $5000 \mathrm{mg} / \mathrm{L}$ as one move towards southern Illinois (Panno et, al. 2017). The increases salinity can increase the density of the water hindering flow between fresh and saline parts of the aquifer. In the local model, all four boundaries were designated as specified head under the assumption that water moved laterally in all directions. These specified head values, like in the regional model were taken from the IGWFM.

\section{Regional Model Boundary Conditions}

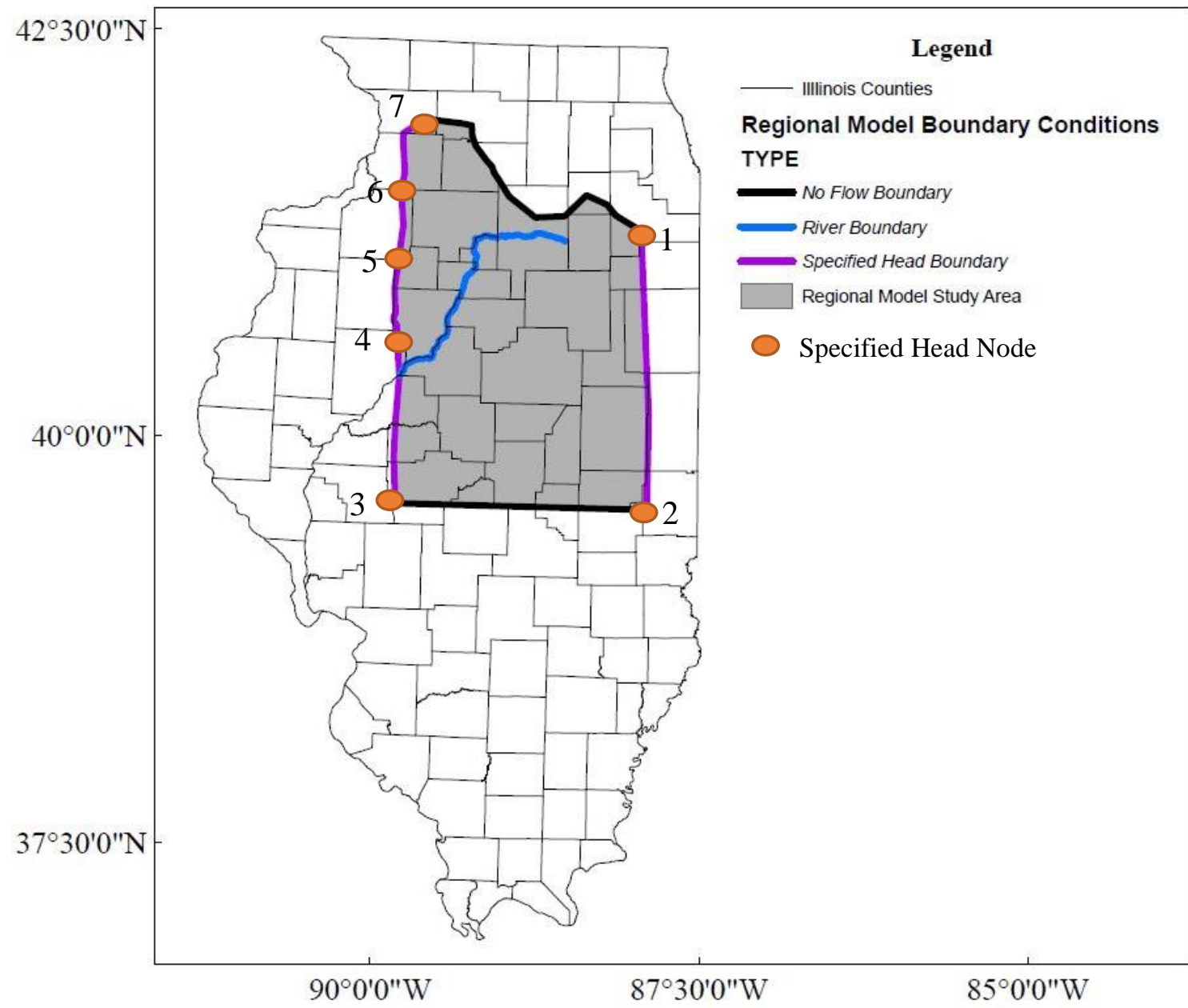

Figure 8. Regional model boundary conditions. Head at point 1 is $61.404 \mathrm{~m}$. Point 2 is $194 \mathrm{~m}$. Point 3 is $177 \mathrm{~m}$. Point 4 is $145 \mathrm{~m}$. Point 5 is $138 \mathrm{~m}$. Point 6 is $155 \mathrm{~m}$. Points 7 is $234.2 \mathrm{~m}$. Specified head conditions based on the computed heads values from IGWFM (Abrams et. al, 2017). 


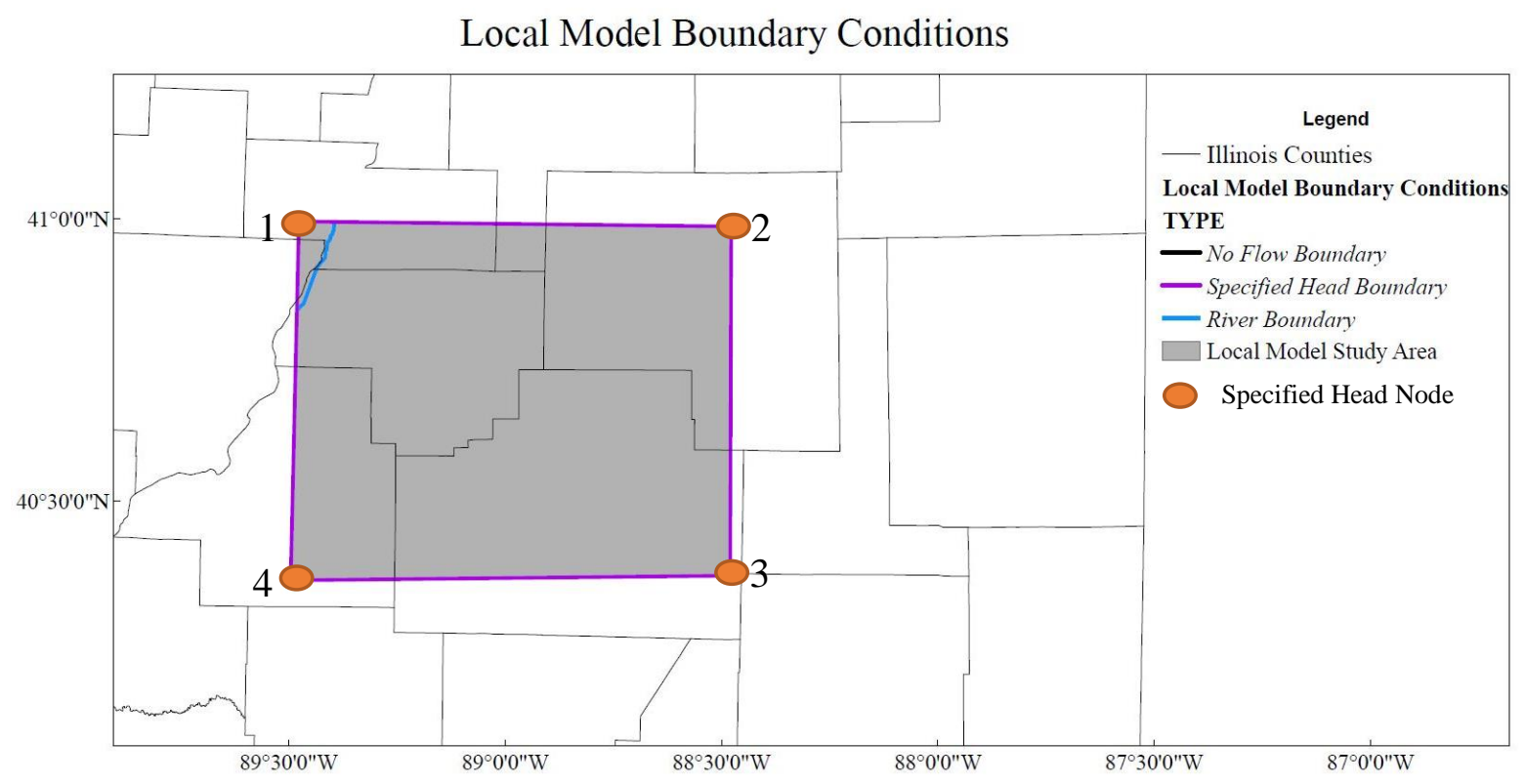

Figure 9. Local model boundary conditions. Point 1 is $148 \mathrm{~m}$. Points 2 is $136 \mathrm{~m}$. Points 3 is 172 $\mathrm{m}$. Point 4 is $180 \mathrm{~m}$. Specified head conditions based on the computed heads values from the IGWFM (Abrams et. al, 2017).

River Boundary

A river boundary is a boundary where the river meets the water level of an aquifer. At this connection, water can flow to and from the river depending on head of the aquifer, the stage of the river and type of material of the river bed. The Illinois River shapefile was input into GMS, where the shapefile was mapped onto the conceptual model using the GIS to Feature object tool in GMS. Once the shapefile was mapped to the Illinois River coverage in the conceptual model, the shapefilewas designated as a river boundary in GMS. A river boundary in GMS, needs conductance assigned for the arc and bottom elevation, and head stage at either end of the arc at the nodes. The two ends of our river arc are gage stations at Hardin IL and Seneca IL. In GMS conductance is calculated using the equation 2.

$$
\mathrm{C}=\frac{\mathrm{kA}}{\mathrm{L}}(3)
$$


Where $\mathrm{C}\left(\mathrm{m}^{2} /\right.$ day) is conductance, $\mathrm{K}(\mathrm{m} /$ day) is hydraulic conductivity of the material, and A $\left(\mathrm{m}^{2}\right)$ is the area of the river. $\mathrm{K}$ was estimated using the properties of the river bottom material. $\mathrm{L}$ is the thickness river bed and was taken from Bhomik and Schicht, 1980. The bottom of the river is composed of well-graded fine to medium sand with diameters less than $5 \mathrm{~mm}$ (Bhomik and Schicht, 1980). Hydraulic conductivity value for this material was estimated to be $10^{-6} \mathrm{~m} / \mathrm{d}$ (Freeze and Cherry, 1979). A was calculated using equation 3:

$$
\mathrm{A}=\mathrm{l} * \mathrm{~W}(4)
$$

Where 1 is the length of the river (l) and $\mathrm{w}$ is the width of the river. Length of the river (l) was estimated using Google Maps measuring tool starting from Hardin, Illinois to Seneca, Illinois, which is about 340,000 meters. The width of the Illinois River was also estimated using Google earth's measuring tool at each gaging station and averaged. The average width was calculated to be approximately 445 meters.

Next, the river boundary needed bottom elevations at the two ending gage stations, Hardin and Seneca. Each of the stream gages were imported into ArcMap and had the elevation extracted into it using the extract Multi Values to Points tool, this elevation is the bottom elevation of the Illinois River at that point. The respective bottom elevation was added to the two ending nodes of the river boundary.

Illinois River data were downloaded from the USGS's National Water Information System: Web Interface from a total of 6 gage stations along the river. Each gage was downloaded as a text file and contained location, date, time, and gage height in feet. Due to the large amount of data from gage stations, average gage height in meters was calculated for the Seneca and Hardin gages in RStudio. The average for each station was added at the respective 
node of the river boundary as head-stage in meters. GMS then interpolated head-stage and bottom elevation along the river boundary arc.

\section{Hydraulic Conductivity}

Hydraulic conductivity values used in the model were based on hydraulic conductivity values from the IGWFM. The different hydraulic conductivity values were separated into different zones and made into a zonal maps by Abrams et al. (2018). These zonal maps were made georeferenced and converted into TIF files in ArcMap and then uploaded to GMS. The different zones were outlined in GMS to create zonal maps as seen in Figure 10. Once the arc were created, polygons were created using the build polygon tool on the feature class tab. Hydraulic conductivity values used in this study can be found in Table 2.

The St. Peter Sandstone dipping southward, as a result it increases in depth as you go south from the Sandwich Fault Zone. With an increase depth there is a decrease in porosity and permeability especially with the Cambrian-Ordovician Sandstones due to increases pressure on pore spaces and quartz overgrowths (Medina et al., 2010). This reduction results from mechanical compaction and age, varying between basins. 


\section{Hydraulic Conductivity Zones}

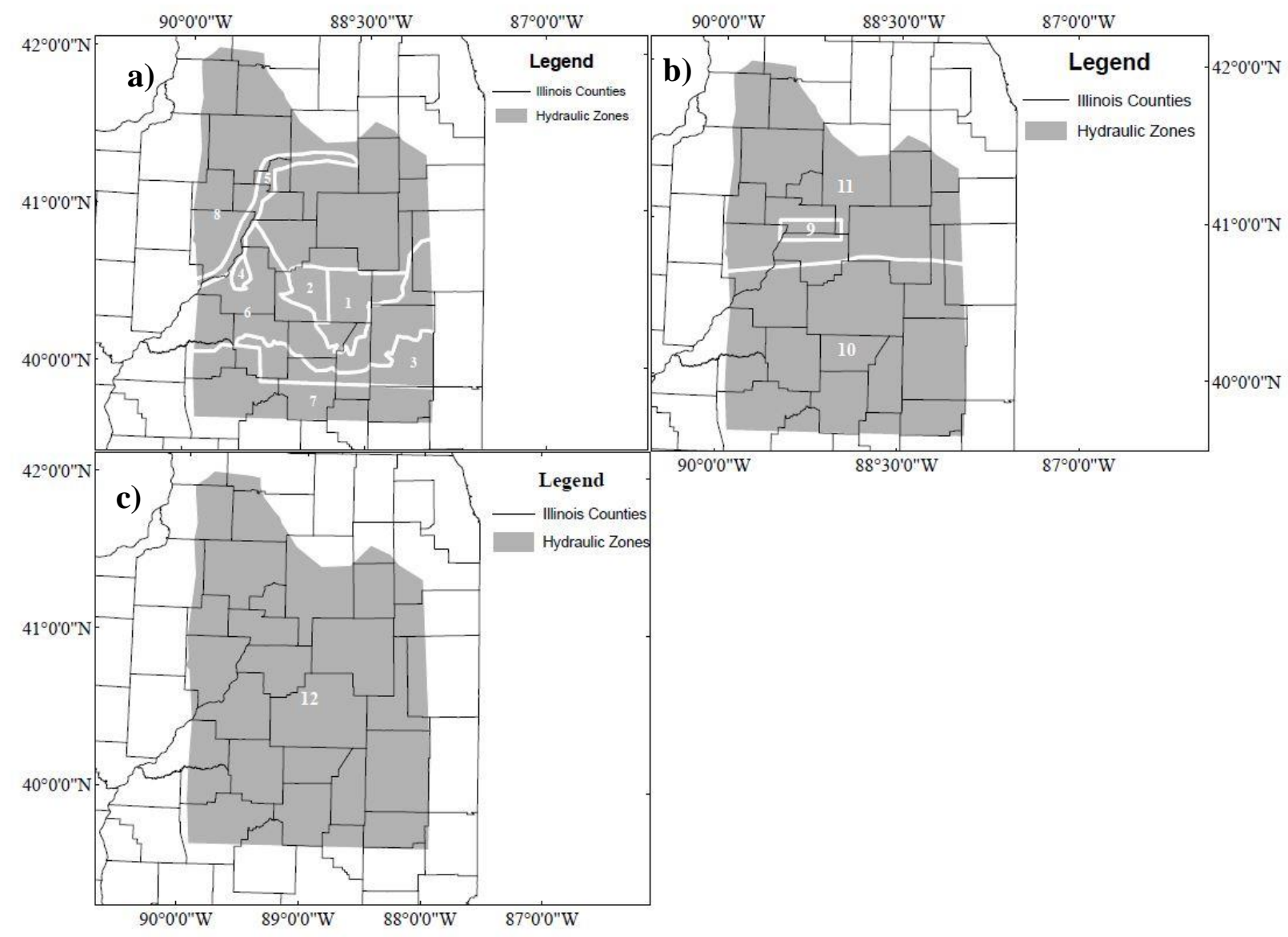

Figure 10. Hydraulic conductivity zone map of the model. Hydraulic conductivity values based on IGWFM (a) Hydraulic conductivity zones of Layer 1, which constitutes the glacial till, carbonate, and shale layers; (b) Hydraulic conductivity zones of Layer 2, the St. Peter Aquifer; and (c) Hydraulic conductivity zones of Layer 3, the underlying aquitard. 
Table 2 List of hydraulic conductivity zones and associated values for the calibrated regional and local models.

\begin{tabular}{|c|c|c|c|c|c|}
\hline Zone & Layer & $\begin{array}{c}\mathbf{K}_{\mathbf{x}} \text { Regional } \\
\text { Model (m/d) }\end{array}$ & $\begin{array}{c}\mathbf{K}_{\mathbf{y}} \text { Regional } \\
\text { Model }(\mathbf{m} / \mathbf{d})\end{array}$ & $\begin{array}{c}\mathbf{K}_{\mathbf{x}} \text { Local Model } \\
(\mathbf{m} / \mathbf{d})\end{array}$ & $\begin{array}{c}\mathbf{K}_{\mathbf{y}} \text { Local } \\
\text { Model }(\mathbf{m} / \mathbf{d})\end{array}$ \\
\hline 1 & 1 & 0.000109728 & 0.000012192 & 0.000109728 & 0.000012192 \\
\hline $2^{*}$ & 1 & 0.000109728 & 0.000012192 & 10 & 10 \\
\hline 3 & 1 & 0.000109728 & 0.000012192 & 0.000109728 & 0.000012192 \\
\hline 4 & 1 & 0.000109728 & 0.000012192 & 0.000109728 & 0.000012192 \\
\hline 5 & 1 & 45.72 & 45.72 & 45.72 & 45.72 \\
\hline 6 & 1 & 83.82 & 10.668 & 40.0 & 15.0 \\
\hline 7 & 1 & 30.48 & 24.384 & 30.48 & 24.384 \\
\hline 8 & 1 & 20.32000366 & 16.25600102 & 4.0 & 4.0 \\
\hline 9 & 2 & 2.0 & 2.0 & 0.03 & 0.03 \\
\hline $10^{*}$ & 2 & 0.8 & 0.8 & 1.0 & 1.0 \\
\hline 11 & 2 & 2.0 & 2.0 & 1.4 & 1.4 \\
\hline $12^{*}$ & 3 & 0.002084832 & $2.08483 \mathrm{e}-006$ & 0.002084832 & $2.08483 \mathrm{e}-006$ \\
\hline
\end{tabular}

Recharge

Recharge rates were estimated to be $2.47 \times 10^{-6} \mathrm{~m} / \mathrm{d}$. This was calculated by taking estimate of $900 \mathrm{~mm} / \mathrm{y}$ and converting it to $0.00247 \mathrm{~m} / \mathrm{d}$ of rainfall. Average recharge value $1 \%$ of rainfall was assumed.

\section{Discharge from Pumping Wells $(Q)$}

There are 44 municipal wells that pumped solely from the St. Peter Aquifer. Form the 44 wells, only 27 had pumping rates for the year 2013. These wells were designated as wells within the GMS program. For the regional model, 21 observation wells were used for calibrating head values after the model run. In our local model, there were 9 wells that had pumping for the year 2013 in the local study area. List of municipal wells used in this study can be found in Table 3 . 
Table 3. List of pumping wells used in the regional and local model. The final calibrated pumping rates used in both models are listed. All pump rates listed in $\left(\mathrm{m}^{3} / \mathrm{d}\right)$ and are negative in because it is modeling water leaving the system.

\begin{tabular}{|c|c|c|c|}
\hline API Number & $\begin{array}{c}2013 \text { In-Situ Pump Rate } \\
\left(\mathrm{m}^{3} / \mathrm{d}\right)\end{array}$ & $\begin{array}{c}\text { Regional Model } \\
\text { Pump rate } \\
\left(\mathrm{m}^{3} / \mathrm{d}\right)\end{array}$ & $\begin{array}{l}\text { Local Model Pump } \\
\text { Rate }\left(\mathbf{m}^{3} / \mathbf{d}\right)\end{array}$ \\
\hline 121130097000 & 0 & 0 & -300 \\
\hline 121132313300 & 0 & -1000 & -1000 \\
\hline 121130000300 & 0 & 0 & -2000 \\
\hline 121132483300 & 0 & -740 & \begin{tabular}{|l|}
-850 \\
\end{tabular} \\
\hline 121973676300 & \begin{tabular}{|l|}
-166.9877 \\
\end{tabular} & -10000 & $\mathrm{NA}$ \\
\hline 121970139100 & -290.2975 & -10000 & $\mathrm{NA}$ \\
\hline 121974274000 & -135.8001 & -135.8 & $\mathrm{NA}$ \\
\hline 120630143500 & 0 & 0 & NA \\
\hline 120632272400 & 0 & -10000 & $\mathrm{NA}$ \\
\hline 120632333600 & \begin{tabular}{|l|}
-158.87 \\
\end{tabular} & -158.87 & NA \\
\hline 120630139100 & 0 & -100 & $\begin{array}{l}\mathrm{NA} \\
\end{array}$ \\
\hline 122032253400 & \begin{tabular}{|l|}
-185.9704 \\
\end{tabular} & $\begin{array}{l}-185.97 \\
\end{array}$ & -650 \\
\hline 122030018400 & \begin{tabular}{|l|}
-228.4249 \\
\end{tabular} & -228.425 & -500 \\
\hline 122032099500 & \begin{tabular}{|l|}
-229.9385 \\
\end{tabular} & \begin{tabular}{|l|}
-229.939 \\
\end{tabular} & -1000 \\
\hline 120110016400 & 0 & -100 & -2600 \\
\hline 120110007500 & 0 & 0 & NA \\
\hline 121050035400 & 0 & 0 & 0 \\
\hline 121050041300 & \begin{tabular}{|l|}
-3379.378 \\
\end{tabular} & -300 & -600 \\
\hline 121052252200 & 0 & 0 & 0 \\
\hline 121050047900 & 0 & 0 & NA \\
\hline 121430164000 & 0 & -500 & $\begin{array}{l}\mathrm{NA} \\
\end{array}$ \\
\hline 121430108100 & 0 & 0 & NA \\
\hline 121430159500 & \begin{tabular}{|l|}
-565.4689 \\
\end{tabular} & $\begin{array}{l}-565.469 \\
\end{array}$ & NA \\
\hline 121230011200 & -544.7132 & -544.713 & -2600 \\
\hline 121230006400 & -319.0438 & -319.044 & -2600 \\
\hline 121432586400 & -330.8081 & -330.808 & NA \\
\hline 121430083400 & 0 & 0 & NA \\
\hline 121433521000 & \begin{tabular}{|l|}
-330.8081 \\
\end{tabular} & -330.808 & NA \\
\hline 121433549400 & \begin{tabular}{|l}
-620.5209 \\
\end{tabular} & -620.521 & NA \\
\hline 121230012500 & 0 & 0 & 0 \\
\hline 121230003300 & \begin{tabular}{|l|}
-303.4122 \\
\end{tabular} & -303.412 & \begin{tabular}{|l|}
-303.412 \\
\end{tabular} \\
\hline 121232064800 & \begin{tabular}{|l|}
-311.3951 \\
\end{tabular} & -311.395 & \begin{tabular}{|l|}
-311.3951 \\
\end{tabular} \\
\hline 121232077700 & \begin{tabular}{|l|}
-319.1451 \\
\end{tabular} & -319.145 & \begin{tabular}{|l|}
-2600 \\
\end{tabular} \\
\hline
\end{tabular}

(Table Continues) 
Table 3, Continues

\begin{tabular}{|l|l|l|l|}
\hline API Number & $\begin{array}{l}\text { 2013 In-Situ Pump Rate } \\
\left(\mathbf{m}^{\mathbf{3}} / \mathbf{d}\right)\end{array}$ & $\begin{array}{l}\text { Regional Model } \\
\text { Pump rate } \\
\left(\mathbf{m}^{\mathbf{3}} / \mathbf{d}\right)\end{array}$ & $\begin{array}{l}\text { Local Model Pump } \\
\text { Rate }\left(\mathbf{m}^{\mathbf{3}} / \mathbf{d}\right)\end{array}$ \\
\hline 120990028600 & 0 & 0 & NA \\
\hline 120992577900 & -168.2058 & -168.206 & NA \\
\hline 120990004300 & -1725.436 & 0 & NA \\
\hline 120990050800 & -350.3247 & -350.325 & NA \\
\hline 120990067100 & 0 & 0 & NA \\
\hline 120992362700 & 0 & 0 & NA \\
\hline 120990235700 & -803.0793 & -803.079 & NA \\
\hline 120630093600 & 0 & 0 & NA \\
\hline 120910030100 & 0 & 0 & NA \\
\hline 120910023000 & -48.77498 & -48.775 & NA \\
\hline 120910040600 & 0 & 0 & NA \\
\hline
\end{tabular}

Observation Wells

In order to test if the results of the model matched well with in-situ head values, in-situ observational data from the St. Peter Aquifer were needed. Location and water level of observation well in the St. Peter Aquifer are shown in Table 4. Eight observation wells are present within the local model with consistent head datum provide by the ISWS. Additional head observations (pseudo observations wells) were created based on the calibrated head values from the IGWFM. The pseudo observation wells were created to give our model more points to calibrate the model. These pseudo observation wells were created in this area due to the local of in-situ observation wells. These wells were given a lower observation head confidence of $10 \%$.

Table 4. Observation wells used to calibrate the regional model API number is assigned by the ISGS's ILOIL and ILWATER data base. Geographic location in NAD 1983 coordinate system.

\begin{tabular}{|l|l|l|l|l|}
\hline $\begin{array}{l}\text { API } \\
\text { Number }\end{array}$ & $\begin{array}{l}\text { Latitude } \\
(\mathbf{Y})\end{array}$ & $\begin{array}{l}\text { Longitude } \\
(\mathbf{X})\end{array}$ & Head (m) & $\begin{array}{l}\text { Model (Local, } \\
\text { Regional, Both) }\end{array}$ \\
\hline $\begin{array}{l}12143258640 \\
0\end{array}$ & 40.77697 & -89.9648 & 130.4544 & Regional \\
\hline $\begin{array}{l}12099257790 \\
0\end{array}$ & 41.14315 & -89.0571 & 138.3792 & Regional \\
\hline
\end{tabular}

(Table Continues) 
Table 4, Continued

\begin{tabular}{|c|c|c|c|c|}
\hline API Number & Latitude (Y) & Longitude $(\mathrm{X})$ & Head (m) & $\begin{array}{l}\text { Model (Local, } \\
\text { Regional, Both) }\end{array}$ \\
\hline 120632272400 & 41.29129 & -88.2546 & 59.1312 & Regional \\
\hline 121050041300 & 41.00061 & -88.5164 & 140.5128 & Both \\
\hline 121130097000 & 40.75015 & -88.7183 & 150.876 & Both \\
\hline 121130000300 & 40.74585 & -88.7214 & 142.6464 & Both \\
\hline 121230011200 & 41.0014 & -89.1344 & 142.3416 & Both \\
\hline 121230006400 & 41.00771 & -89.1365 & 126.7968 & Regional \\
\hline 121230003300 & 41.0521 & -89.0513 & 120.0912 & Regional \\
\hline 121430159500 & 40.92363 & -89.7602 & 136.8552 & Regional \\
\hline 121970139100 & 41.26489 & -88.2145 & 54.2544 & Regional \\
\hline 122030018400 & 40.90155 & -89.0395 & 133.5024 & Both \\
\hline 122032099500 & 40.9034 & -89.0415 & 131.3688 & Both \\
\hline 121232064800 & 41.05072 & -89.0513 & 114.9096 & Regional \\
\hline 121973676300 & 41.27092 & -88.2209 & 63.3984 & Regional \\
\hline 120632333600 & 41.18768 & -88.306 & 110.0328 & Regional \\
\hline 122032253400 & 40.90051 & -89.0406 & 130.4544 & Both \\
\hline 121232077700 & 41.0009 & -89.1353 & 91.1352 & Regional \\
\hline 121974274000 & 41.23545 & -88.2387 & 90.2208 & Regional \\
\hline 121433521000 & 40.77764 & -89.9678 & 127.1016 & Regional \\
\hline 121433549400 & 40.93076 & -89.7536 & 140.208 & Regional \\
\hline Pseudo 1 & 40.7220957 & -89.1021719 & 157.0 & Local \\
\hline Pseudo 2 & 40.7287507 & -88.5274838 & 155.0 & Local \\
\hline Pseudo 3 & 40.4678529 & -89.3111072 & 166.0 & Local \\
\hline Pseudo 4 & 40.4738575 & -88.5170096 & 166.0 & Local \\
\hline Pseudo 5 & 40.8921084 & -88.5202428 & 143.0 & Local \\
\hline Pseudo 6 & 40.8614947 & -89.1034358 & 151.0 & Local \\
\hline
\end{tabular}




\section{Regional Model}

\section{$3 D$ Grid}

The conceptual model is converted into a 3D grid in GMS with the dimensions of the 3D grid found in Table 5. All GIS files were converted into a uniform coordinate system, the NAD 1983 UTM Zone 16N coordinate system, before imported unto GMS. The cell size for the $\mathrm{x}$ and $\mathrm{y}$ grids were made into $500 \mathrm{~m}$ by $500 \mathrm{~m}$. The $\mathrm{z}$ direction (our depth) was given an origin of -1300 meters and a length of 1700 meters and was divided vertically into 3 cells to represent unit thickness of the three model layers.

Table 5 Dimensions of the regional 3-D grid in GMS using the NAD 1983 UTM Zone 16N coordinate system.

\begin{tabular}{|c|c|c|c|c|c|}
\hline \multicolumn{2}{|c|}{ X-Dimension } & \multicolumn{2}{c|}{ Y-Dimension } & \multicolumn{2}{c|}{ Z-Dimension } \\
\hline Origin: & 244,000 & Origin: & $4,340,000$ & Origin: & -1300 \\
\hline Length: & 185,000 & Length: & 322,000 & Length: & 1700 \\
\hline Cell Size: & 500 & Cell Size: & 500 & $\begin{array}{c}\text { Number of } \\
\text { Cells: }\end{array}$ & 3 \\
\hline
\end{tabular}

The top and bottom layers' elevation in TIFF file format, created by interpolation of point data extracted from well logs and DEM in ArcMap, was imported into GMS, in GMS, these layers' elevation was used to define elevation of MODFLOW grid. Errors where the interpolated layers overlapped were fixed in GMS by using the MODFLOW model Checker. Using this tool, we ran a check and fixed all the layers by preserving the top layer in each case. Once the 3D grid was created, cross sections of our grid were made and compared to previously established cross sections of the area (Figure 11a-c).

Aquifer properties were then applied to the $3 \mathrm{D}$ grid. This was done by interpolating our conceptual model onto the MODLFOW simulation. Boundaries, K, recharge, and Q were all interpolated from the conceptual model onto the MODLFOW simulation. The northern and 
southern boundaries were interpolated as no flow boundaries. The eastern and western boundaries were designated as specified heads from our conceptual model (Figure 8). 
a)
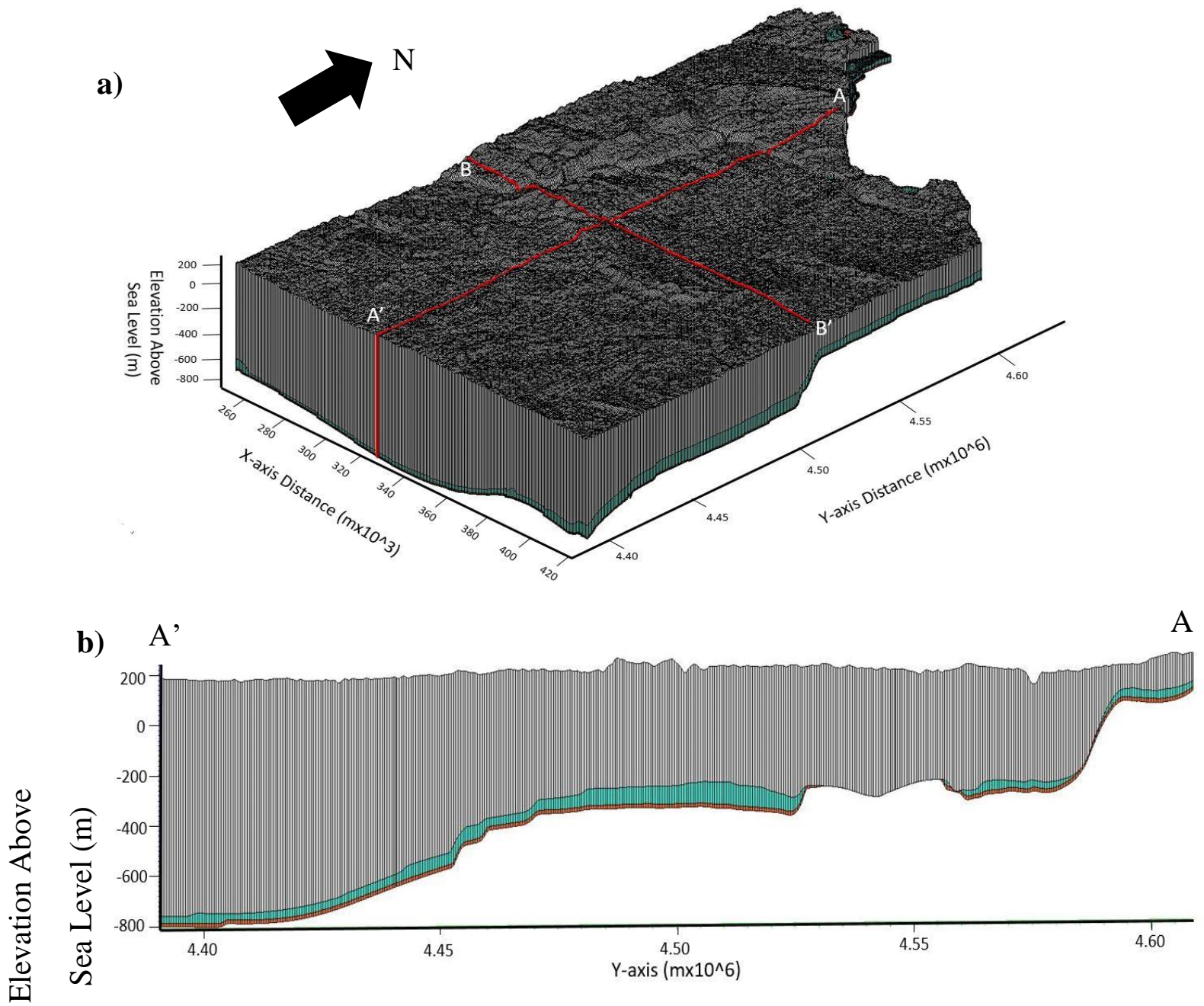

c)

B

B'

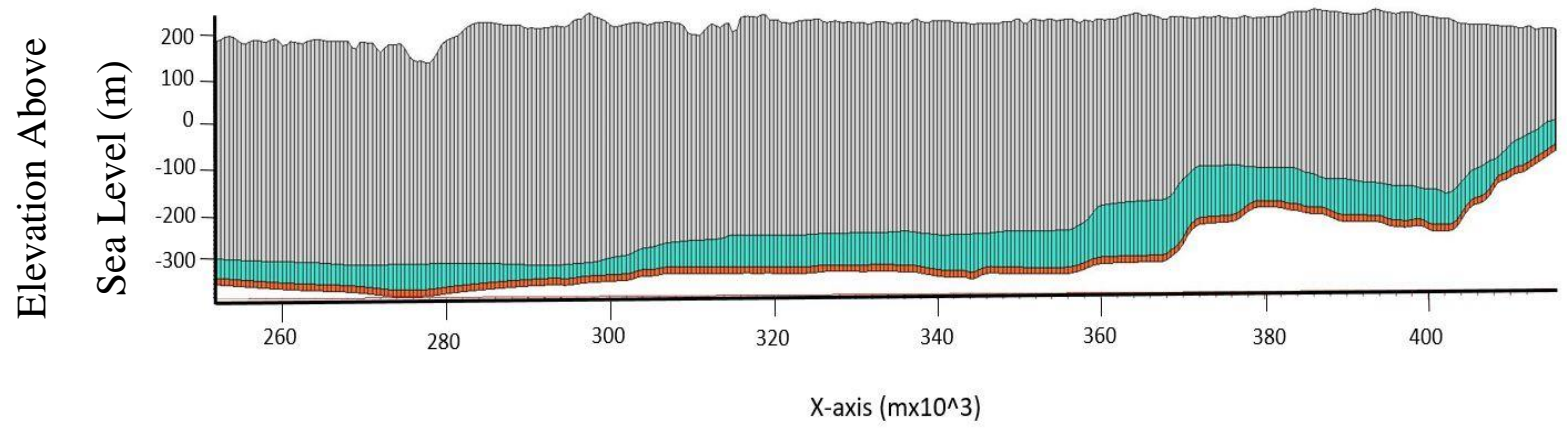

Figure 11. Oblique view and cross sections of regional groundwater model. Model grid shows a) 3D Oblique view of regional groundwater model created using GMS 10.2.3.; b) Cross-section view of groundwater model from A to A'; and c) cross section view of groundwater model from B to B'. 


\section{Local Model}

\section{$3 D$ Grid}

A 3D grid for the local model was then created based off of the regional model. Steps to create a smaller 3D grid were to covert our solution from the regional model and convert the computed heads into scatter points, which can be interpolated onto the local model. The next step was create a new conceptual model, which has the same characteristics ( $\mathrm{K}$, boundary conditions, etc.) as the regional model. The interpolation of the regional model on to the local model made calibrated difficult and the conceptual model and 3D grid of the local model was built independently of the regional model. Like in the regional model, our conceptual model was interpolated onto the MODFLOW layers. This is done by right clicking on the conceptual model and clicking Map to $\rightarrow$ MODFLOW. An oblique view of the local model 3D grid can be found in Figure 12. The dimensions of the 3D grid can be found in Table 6 .

Table 6 Dimensions of the local 3-D grid

\begin{tabular}{|c|c|c|c|c|c|}
\hline \multicolumn{2}{|c|}{ X-Dimension } & \multicolumn{2}{c|}{ Y-Dimension } & \multicolumn{2}{c|}{ Z-Dimension } \\
\hline Origin: & 282961.00281451 & Origin: & 4468166.8810656 & Origin: & -1300 \\
\hline Length: & 95457.938080804 & Length: & 77728.616557606 & Length: & 1700 \\
\hline Cell Size: & $\mathrm{n} / \mathrm{a}$ & Cell Size: & $\mathrm{n} / \mathrm{a}$ & $\begin{array}{c}\text { Number of } \\
\text { Cells: }\end{array}$ & 3 \\
\hline
\end{tabular}

The differences between the local and the regional model are the location of the boundary conditions, in our case the specified head conditions. In the local model, specified head boundary conditions were applied to all the boundaries not just the western and eastern boundaries (Figure 9). K zones stayed the same in the local model as they were in the regional model, but calibration of the local model resulted in differing $\mathrm{K}$ values. Pumping was also calibrated independently of the regional model due to the local model having different dimensions than the regional model. 


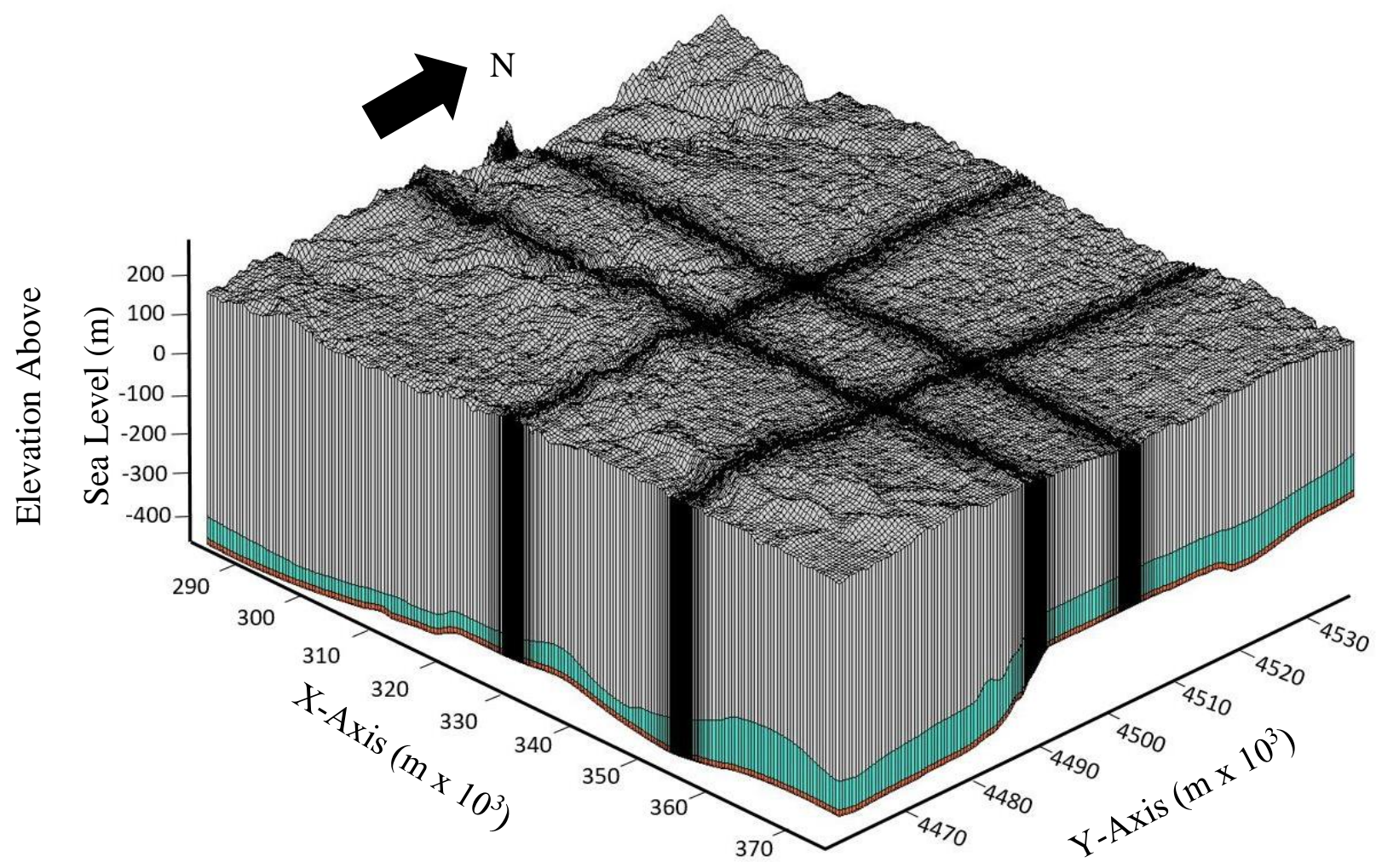

Figure 12. Oblique view of $3 \mathrm{D}$ mesh grid of localized model.

\section{Telescopic Grid Refinement (TGR)}

For the purpose of creating a detail subarea (near Bloomington wells) from the regional model, a telescopic grid refinement technique was used. The TGR (or the local) model is a separate model that uses the results from a lager model in order to define the boundary conditions of the TGR model. After the regional model was run and calibrated, a local model around the new Bloomington wells was created. In the absence of any physical or hydraulic boundaries in a small-scale model, TGR method is advantageous. Further, pumping causes steep gradients in the head near the well. In order to accurately model, the flow and gradient near Bloomington wells, the grid in the local model was refined in vicinity of the wells. This was accomplished by applying, for this model, a bias size (the smallest) of $5.0 \mathrm{~m}$, with a bias of 1.1 
(grid size varies by $10 \%$ increment away from the wells), and a maximum grid cell size of $500 \mathrm{~m}$ to match the grid cell size of the regional model and reduce model run time.

In the local model, the Grid Refinement (GR) method was applied at the Bloomington and Chenoa wells to limit each grid cell to one pumping well for easier calibration. Initially in the model, the parameters used in the TGR method were a base size of 5 meters, bias of of $10 \%$, and a maximum cell size of $500 \mathrm{~m}$. These parameters mean that the grid around your center cell (in our case the Bloomington and Chenoa pumping wells) had a base cell size of $5 \mathrm{~m} \times 5 \mathrm{~m}$. Every cell away from center cell grew by $10 \%$ (bias) until a maximum size of $500 \mathrm{~m}$ was reached (Figure 13).

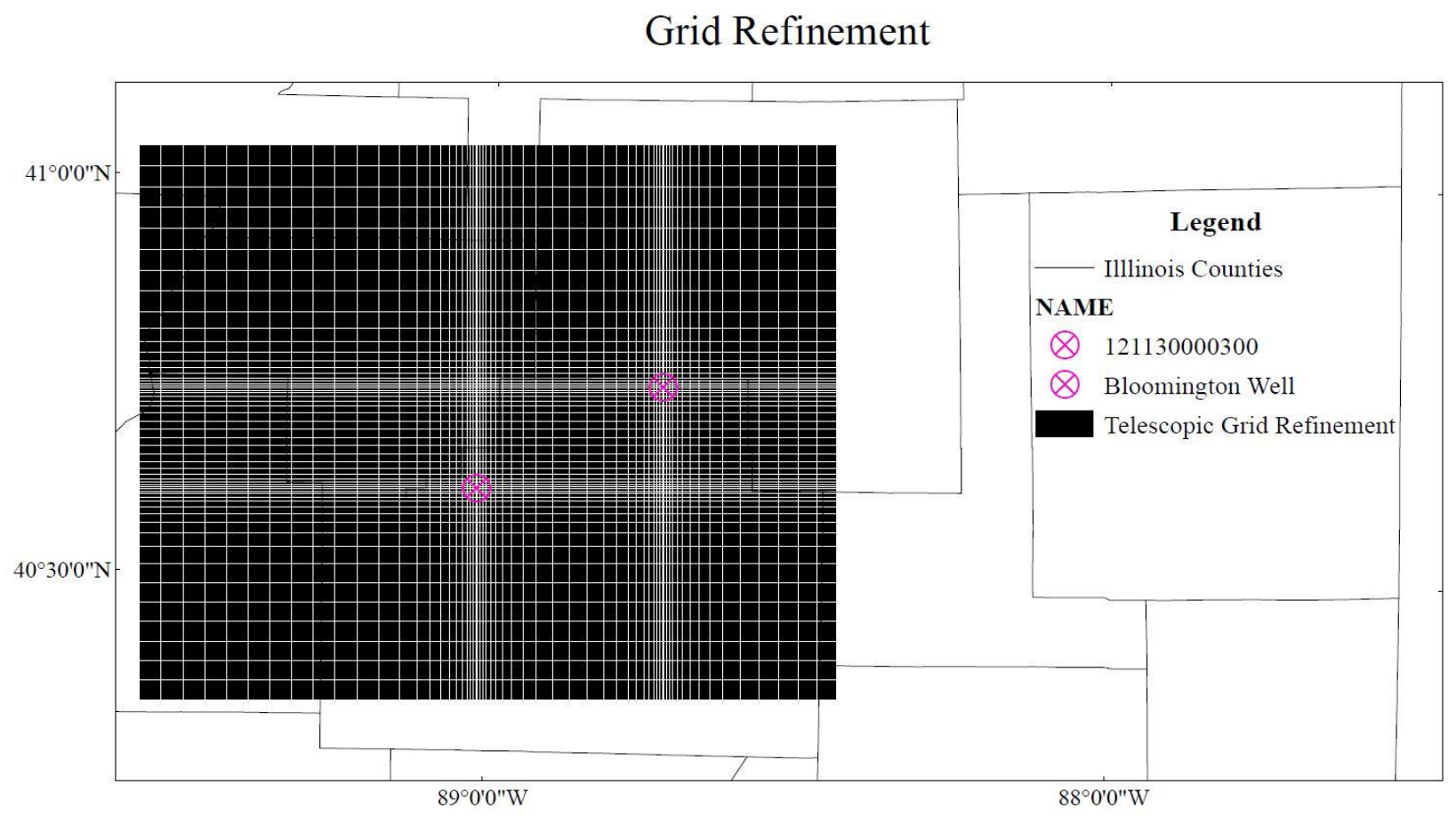

Figure 13. Planar view of GR method applied around the Bloomington and Chenoa wells The model was run without discharge $(\mathrm{Q})$ from the pumping test of the Bloomington well to compute a static water level. The model computed a head of $159 \mathrm{~m}$ without $\mathrm{Q}$ from the Bloomington Well. When discharge from the pumping test was added to the model run, there 
was a 39 meter drawdown compared to the pumping test in-situ drawdown of $10 \mathrm{~m}$. The GR method and aquifer parameters were calibrated to match the pumping test drawdown of $10 \mathrm{~m}$. The final GR parameters were a base cell size of $20 \mathrm{~m}$, bias of $10 \%$, and maximum cell size of $500 \mathrm{~m}$.

\section{Uncertainty Analysis}

Due to a lack of information about the aquifer characteristics of the St. Peter Aquifer, a stochastic model was run with model uncertainty that could arise from parameter uncertainty. The stochastic modeling approach involves running a large number of model runs to explore the range of predictive possibilities rather than making a discrete prediction (Hunt et al., 2007). The advantage of a stochastic approach is the ability to merge multiple sources of information and to estimate error distributions and report uncertainty in estimates (Keir et al., 2019). This method provides an efficient means of exploring predictive uncertainty by generating many different parameter fields all of which honor calibration constraints (Sreekanth et al., 2017). In a nonstochastic modeling-approach, a single model is developed that represents the best estimate for the real world system being simulated. In a stochastic modeling approach, a set of models is constructed where each model in the set is thought to be equally probable.

The stochastic modeling method applied was the Random Sampling method. In this method, a random number is generated for each parameter according to the specified distribution using the mean, standard deviation, maximum, and minimum. In this study, 50 realizations that are conditioned to the aquifer characteristics were run with differing hydraulic conductivity values for the St. Peter Aquifer (Layer 2) and recharge. Hydraulic conductivity values for zones 10 and 11 (Figure 10) range from 0.1 to $5.0 \mathrm{~m} / \mathrm{d}$, whereas hydraulic conductivity values for zone 9 range from 0.001 to $1.0 \mathrm{~m} / \mathrm{d}$ for the stochastic model simulation. Recharge values for layer 1 
ranged from $2.1 \times 10^{-8}$ to $2.1 \times 10^{-6} \mathrm{~m} / \mathrm{d}$ and was applied to zones. A table with the values used in the 50 realizations can be found in Table A1.

This study focused mostly on the effect of $\mathrm{K}$ on changes in water level in the area surrounding the Bloomington well. In order to isolate computed head in the cells surrounding the Bloomington well, the head solution from each of the 50 stochastic model simulations was download as a text file from GMS. The downloaded text file was then interpolated in R. The Rscript read all 50 text files and sub-set computed head values for the following cells in the 3D grid; 123791:12793, 124082:124084, 124373:124375. Figure 13 shows the 9 cells of interest and the location of the Bloomington well.

\begin{tabular}{|c|c|c|}
\hline 123791 & 123792 & 123793 \\
& & \\
\hline 124082 & 124083 & 124084 \\
& Bloomington Well & \\
& & \\
& 124374 & 124375 \\
\hline 124373 & & \\
& & \\
\hline
\end{tabular}

Well

Figure 14. Planar view of the surrounding 9 grid cells around Bloomington Well. The center cell outlined in blue is $20 \mathrm{~m}$ by $20 \mathrm{~m}$. Each of the surrounding cells is $22 \mathrm{~m}$ by $22 \mathrm{~m} \mathrm{(10} \mathrm{bias} \mathrm{for} \mathrm{the}$ stochastic model). Bloomington well is shown in cell 124083.

Stochastic method was applied to see how sensitive the model was to changing parameters. In an uncertainty analysis the model is checked for stability and sensitivity. Stability and sensitivity are assessed by changing the parameters of the model and measuring the change in head. If the change in head varies greatly or doesn't converge then our model is not stable. To test for instability the aquifer parameters changed were the hydraulic conductivity (K) of the St. 
Peter Sandstone. Due to the lack of calibration data in this area we decided to take a stochastic modeling approach to measure uncertainty.

\section{Predictive Model}

In order to test the hypothesis regarding the estimation of sustainable yield, the local model was used to predict drawdown for variable pumping scenarios. The discharge rate of the Bloomington well was changed based on predicted water demands for the city of Bloomington, IL.

Projected water demands by the city of Bloomington were based off of the city's Water Supply plan (http://www.cityblm.org/home/showdocument?id=4192). The water supply plan estimated a demand of 14 MGD or $52995.8 \mathrm{~m}^{3} /$ day by the year 2020 . This estimation was based on the following equation:

$$
y=(0.00427 * x)-5.2035(5)
$$

Where:

$$
\begin{aligned}
& y=\text { average-day demands (mgd); and } \\
& x=\text { time, set to } 12 / 31 \text { of each year (Julian Days) }
\end{aligned}
$$

Since the city of Bloomington will still be using Lakes Evergreen and Bloomington as their main sources of water, there is no need to pump $52995.8 \mathrm{~m}^{3} / \mathrm{d}$ from the aquifer. If we assume that the city uses $5 \%$ of projected water demand to dilute the lake water, a scenario a can be made where the St. Peter Aquifer accounts for 5\% of the city's water supply. This 5\% of 52995.8 $\mathrm{m}^{3} / \mathrm{d}$ results in a pumping rate of $2649.8 \mathrm{~m}^{3} / \mathrm{d}$ to meet $5 \%$ of Bloomington's hypothesized water needs.

In order to estimate sustainable yield, we took a pseudo-transient modeling approach. In a real transient model, pumping is applied for period of time at specified intervals or timeframes. 
At each timeframe the model takes into account pumping and head from the previously run timeframe. In the pseudo-transient modeling approach, the pumping rate is increased manually at each timeframe and does not take into account the change in head from the previous timeframe. In practice this means for each first timeframe a pumping rate of $2649.8 \mathrm{~m}^{3} / \mathrm{d}(5 \%$ of Bloomington's predicted demand) was applied to the well and run. In the next timeframe, the pumping rate of the Bloomington well was increased to $5299.6(2649.8 * 2)$ and the model was run again. The pumping rate was increased for each timeframe until the cell containing the Bloomington well was dry. After manually changing the pumping rate in GMS and running the model, the new dynamic head was recorded onto a spreadsheet for each timeframe. 


\section{CHAPTER IV: RESULTS}

\section{Calibration}

Calibration was done by adjusting model parameters and rerunning the model multiple times until the model's computed heads values matched the in-situ head values from observation wells. The in-situ head data used to calibrate our model are shown in Table 4 and Figure 15. Head datum from 2014 were used to calibrate the model corresponding to the pumping rate datum used to run the model which were from the 2013.Additional pseudo observation wells were created based on head values obtained from the calibrated IGWFM (Abrams et al., 2018) to supplement the observation well datum and better calibrate the local model. A large confidence interval (90\%) was assigned for the observation wells while low confidence interval (10\%) was assigned for the pseudo wells.

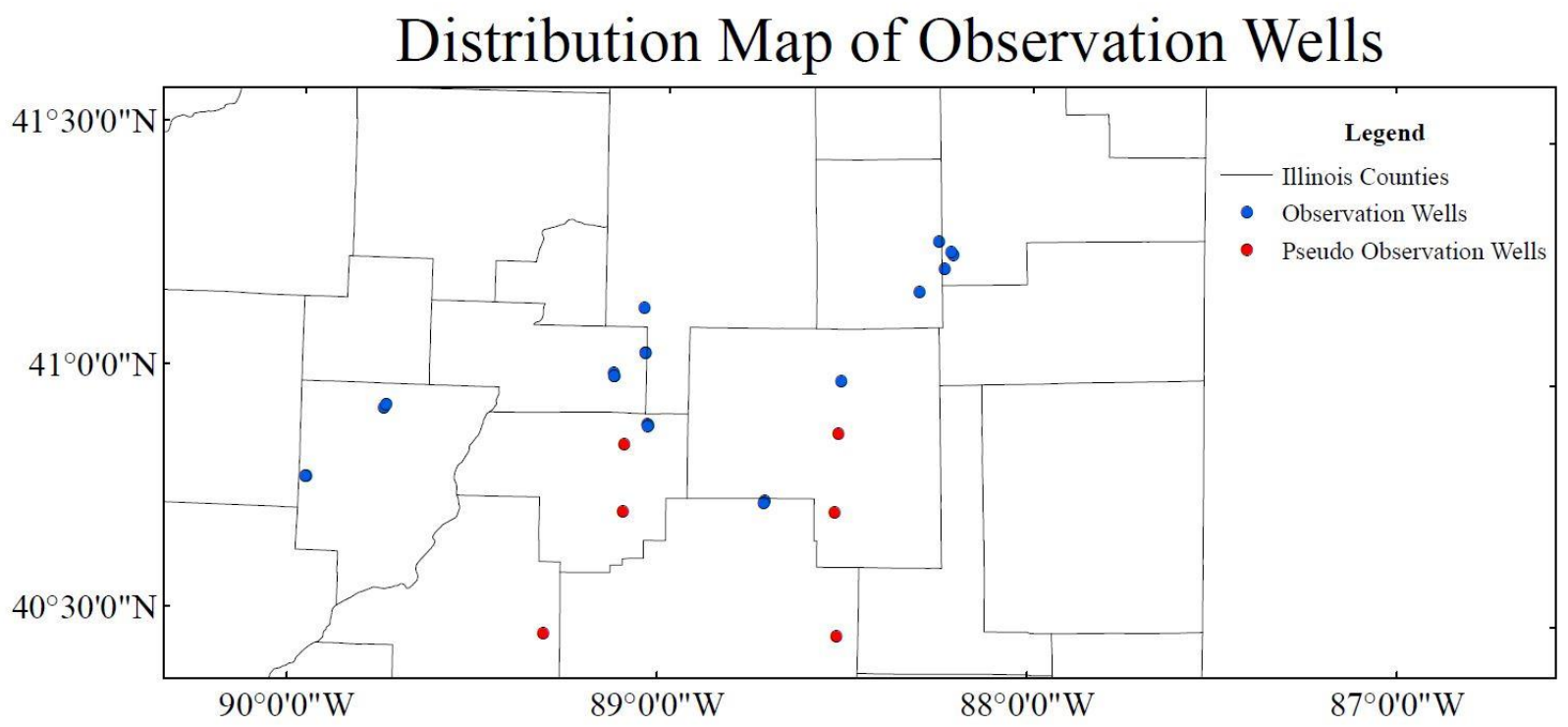

Figure 15. Distribution map of observation wells. Observation wells provided by the ISWS. Confidence interval of $90 \%$. Pseudo wells were only used in calibration of the local models and were given a 10\% confidence interval based on Abrams et al. 2018 model. 


\section{Regional Model}

The parameters that needed to be calibrated for the regional model were the hydraulic conductivity (K) of Layers 1 and 2 as well as the pumping rate (Q) from municipal wells. When initially running the groundwater model, many wells were overestimating head, this could be due to underestimation of the pumping rates used, which were from 2013. The reason for calibrating the pumping wells is because steady-state model only models pumping for one timeframe. In order to account for years of pumping in a steady-state model, we increased pumping from wells that have been in operation for multiple years. In addition, pumping datum was not complete, several pumping wells with missing data. Therefore, it was necessary to calibrate the pumping rate. After manually calibrating the regional model, the final parameters obtained for the regional model can be found in Tables 2 and 3 ( $\mathrm{K}$ and $\mathrm{Q}$ respectively) in the methodology section. The final statistics for the regional model can found in Table 7.

Table 7. Performance measure statistics for the regional model

\begin{tabular}{|l|l|}
\hline Item & Value \\
\hline Mean Residual (Head) & $-16.18 \mathrm{~m}$ \\
\hline Mean Absolute Residual (Head) & $19.35 \mathrm{~m}$ \\
\hline Root Mean Squared Residual (Head) & $23.88 \mathrm{~m}$ \\
\hline Mean Residual (Flow) & $0 \mathrm{~m}$ \\
\hline Absolute Residual (Flow) & 0 \\
\hline Root Mean Squared Residual (Flow) & 0 \\
\hline Mean Weighted Residual (Head+Flow) & -31.71 \\
\hline Mean Absolute Weighted Residual (Head+Flow) & 37.93 \\
\hline Root Mean Squared Weighted Residual (Head+Flow) & 46.8 \\
\hline Sum of Squared Weighted Residual (Head+Flow) & 46002.36 \\
\hline Displayed Precision & 2 \\
\hline
\end{tabular}

In the regional model the Root Mean Residual Error was 16.18 m and the Root Mean Squared Weighted Residual was $46.80 \mathrm{~m}$. Residual Head values for observation wells used in the regional model can be found in Table 8 below. To answer the first research question, using the regional numerical model, manual and automated calibration techniques along with sensitivity 
analysis were implemented to mimic the historical potentiometric surfaces and determine the aquifer characteristics (e.g., K, Ss).

Table 8. List of observed, computed, and residual heads from the calibrated regional model.

\begin{tabular}{|l|l|l|l|}
\hline API Number & Observed Head (m) & Computed Head (m) & Residual Head (m) \\
\hline 121432586400 & 130.4544 & 144.0139 & -13.5595 \\
\hline 120992577900 & 138.3792 & 152.7296 & -14.3504 \\
\hline 120632272400 & 59.1312 & 100.3437 & -41.2125 \\
\hline 121050041300 & 140.5128 & 128.3933 & 12.1195 \\
\hline 121130097000 & 150.876 & 136.6148 & 14.2612 \\
\hline 121130000300 & 142.6464 & 136.729 & 5.9174 \\
\hline 121230011200 & 142.3416 & 148.9654 & -6.6238 \\
\hline 121230006400 & 126.7968 & 149.1391 & -22.3423 \\
\hline 121230003300 & 120.0912 & 149.7446 & -29.6534 \\
\hline 121430159500 & 136.8552 & 144.454 & -7.5988 \\
\hline 121970139100 & 54.2544 & 95.61382 & -41.3594 \\
\hline 122030018400 & 133.5024 & 145.7526 & -12.2502 \\
\hline 122032099500 & 131.3688 & 145.837 & -14.4682 \\
\hline 121232064800 & 114.9096 & 149.7097 & -34.8001 \\
\hline 121973676300 & 63.3984 & 96.18962 & -32.7912 \\
\hline 120632333600 & 110.0328 & 112.0129 & -1.9801 \\
\hline 122032253400 & 130.4544 & 145.7613 & -15.3069 \\
\hline 121232077700 & 91.1352 & 148.9543 & -57.8191 \\
\hline 121974274000 & 90.2208 & 102.0889 & -11.8681 \\
\hline 121433521000 & 127.1016 & 144.027 & -16.9254 \\
\hline 121433549400 & 140.208 & 144.5186 & -4.3106 \\
\hline
\end{tabular}

\section{Local Model}

The same model parameters $(\mathrm{K}, \mathrm{Q})$ were calibrated in the local model as were in the regional model. In the local model, heads and boundary conditions were interpolated from the regional model. The effects of calibrating the model parameters on the Bloomington well was seen using the GR method. The boundary conditions interpolated from the regional model made calibration difficult. The interpolated boundary conditions and head values resulted in large residual head error values in the observations wells, especially in those near specified head boundaries. To reduce residual head in these wells in the local model, a different set of boundary 
conditions were applied. These new boundary conditions were directly based off of the IGWFM, by interpolating head calculated by the IGWFM to our local model. The final local model boundary conditions can be found in Figure 9.

The local model statistics are a Mean Residual Error of $0.1 \mathrm{~m}$ and a RMSE of $11.72 \mathrm{~m}$. Final statistics for the local model can be found below in Table 9 with residual head error values for each observation well can be found in table 10 .

Table 9. Statistics from local model using the boundary conditions from the regional model.

\begin{tabular}{|l|l|}
\hline Item & Value \\
\hline Mean Residual (Head) & $0.1 \mathrm{~m}$ \\
\hline Mean Absolute Residual (Head) & $10.77 \mathrm{~m}$ \\
\hline Root Mean Squared Residual (Head) & $11.72 \mathrm{~m}$ \\
\hline Mean Residual (Flow) & 0 \\
\hline Absolute Residual (Flow) & 0 \\
\hline Root Mean Squared Residual (Flow) & 0 \\
\hline Mean Weighted Residual (Head+Flow) & -4.09 \\
\hline Mean Absolute Weighted Residual (Head+Flow) & 12.71 \\
\hline Root Mean Squared Weighted Residual (Head+Flow) & 17.75 \\
\hline Sum of Squared Weighted Residual (Head+Flow) & 4408.68 \\
\hline Displayed Precision & 2 \\
\hline
\end{tabular}

Table 10. List of observed, computed, and residual heads from the calibrated local model.

\begin{tabular}{|l|l|l|l|}
\hline Well & Observed Head $(\mathbf{m})$ & Computed Head $(\mathbf{m})$ & Residual Head $(\mathbf{m})$ \\
\hline 121050041300 & 140.5128 & 138.7262 & 1.78660 \\
\hline 121130097000 & 150.876 & 151.3912 & -0.51520 \\
\hline 121130000300 & 142.6464 & 142.0097 & 0.63670 \\
\hline 121230011200 & 142.3416 & 145.1252 & -2.78360 \\
\hline 122030018400 & 133.5024 & 132.0864 & 1.41600 \\
\hline 122032099500 & 131.3688 & 131.3612 & 0.00760 \\
\hline 122032253400 & 130.4544 & 128.7792 & 1.67520 \\
\hline Pseudo 1 & 157 & 158.4811 & -1.48110 \\
\hline Pseudo 2 & 155 & 152.6553 & 2.34470 \\
\hline Pseudo 3 & 166 & 167.3659 & -1.36590 \\
\hline
\end{tabular}

(Table Continues) 
Table 10, Continued

\begin{tabular}{|l|l|l|l|}
\hline Well & Observed Head $(\mathbf{m})$ & Computed Head $(\mathbf{m})$ & Residual Head $(\mathbf{m})$ \\
\hline Pseudo 4 & 166 & 167.9004 & -1.90040 \\
\hline Pseudo 5 & 143 & 143.9851 & -0.98510 \\
\hline Pseudo 6 & 151 & 153.792 & -2.79200 \\
\hline
\end{tabular}

Bloomington Pump Test

A similar pumping rate used in the Bloomington pumping test was applied in the model

for better calibration and to test aquifer parameters. The Bloomington pumping test was a 24-

hour pumping test to test the viability of the St. Peter Aquifer. The pumping test information and parameters were estimated by the ISWS from the pumping test are found in Table 11.

Table 11. Parameters of the Bloomington Pumping Test

\begin{tabular}{|l|l|}
\hline Parameter & Value \\
\hline Discharge $(\mathrm{Q})$ & $1668 \mathrm{~m}^{3} /$ day \\
\hline Thickness $(\mathrm{b})$ & $70.1 \mathrm{~m}$ \\
\hline Hydraulic Conductivity $(\mathrm{K})$ & $0.946 \mathrm{~m} /$ day \\
\hline Drawdown $(\Delta \mathrm{H})$ & $10.07 \mathrm{~m}$ \\
\hline
\end{tabular}

\section{Calibration}

The final GR parameters were determined by calibrating the model with different hydraulic conductivities and different GR parameters. There was an overestimation in the amount of drawdown in the Bloomington well, which was $19 \mathrm{~m}$. The model was run without the addition of discharge (Q) from the Bloomington Well and a static water level (head) of $156.5 \mathrm{~m}$ was computed. In order to simulate the effects of the Bloomington Pump Test a discharge of $1668 \mathrm{~m}^{3} / \mathrm{d}$ was applied to model. The model was run with the addition of this new $\mathrm{Q}$ and resulted in a computed water level of $127.5 \mathrm{~m}$ or a net drawdown of $29 \mathrm{~m}$. This was an overestimate of 19 meters compared to the pump test, which estimated $\sim 10 \mathrm{~m}$ drawdown. Parameters for the local model were changed to simulate a new drawdown of $10 \mathrm{~m}$ at the Bloomington well. The final calibrated statistics for the GR method and Q for the Bloomington wells are found in table 12. 
Table 12. Final statistics for local model with the GR method applied to the Bloomington and Chenoa wells. These statistics are with Q from the Bloomington well applied.

\begin{tabular}{|c|c|}
\hline Item & Value \\
\hline Mean Residual (Head) & -0.94 \\
\hline Mean Absolute Residual (Head) & 1.62 \\
\hline Root Mean Squared Residual (Head) & 2.4 \\
\hline Mean Residual (Flow) & 0 \\
\hline Absolute Residual (Flow) & 0 \\
\hline Root Mean Squared Residual (Flow) & 0 \\
\hline Mean Weighted Residual (Head+Flow) & -1.21 \\
\hline Mean Absolute Weighted Residual (Head+Flow) & 1.85 \\
\hline Root Mean Squared Weighted Residual & 4.06 \\
\hline (Head+Flow) & 214 \\
\hline Sum of Squared Weighted Residual (Head+Flow) & 2 \\
\hline Displayed Precision & \\
\hline
\end{tabular}

\section{Uncertainty Analysis}

\section{Stochastic Simulation}

In this study, sensitivity of $\mathrm{K}$ tested. The parameters used in the stochastic model are found in Table 13. The results of the stochastic modeling approach can be seen in Figure 16, showing the change in dynamic head with changing $\mathrm{K}$.

Table 13. Parameter estimation of hydraulic conductivity and recharge using the stochastic method. A key value is an improbable value for the parameter which tells the model that is the parameter that needs to be tested.

\begin{tabular}{|l|l|l|l|l|l|}
\hline Zone & \multicolumn{1}{|c|}{ Parameter } & $\begin{array}{c}\mathbf{H}_{\mathbf{k}} \\
(\mathbf{m} / \mathbf{d})\end{array}$ & Key Value & Min $(\mathbf{m} / \mathbf{d})$ & Max (m/d) \\
\hline North & K Layer 2 & 1.4 & -100 & 0.1 & 5 \\
\hline Thin & K Layer 2 & 0.03 & -200 & 0.01 & 1 \\
\hline South & K Layer 2 & 1 & -300 & 0.1 & 5 \\
\hline 1 & Recharge & $2.1 \mathrm{e}-007$ & -400 & $2.1 \mathrm{e}-008$ & $2.1 \mathrm{e}-006$ \\
\hline
\end{tabular}




\section{Hydraulic Conductivity v. Dynamic Head $(\mathrm{m} / \mathrm{d})$}

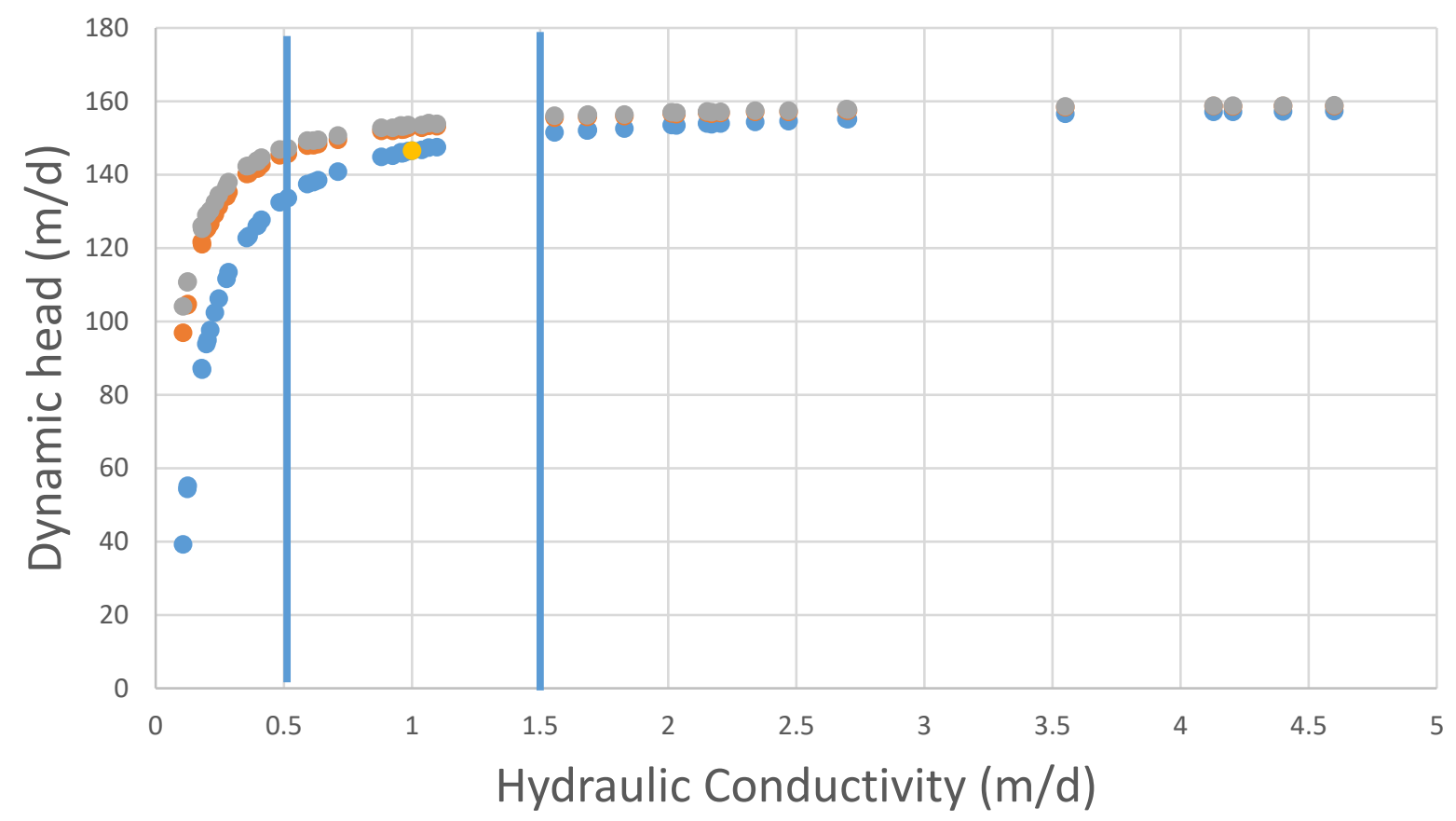

- Head at the well - Head of 9 cells - Head of 8 surrounding wells Calibrated Head

Figure 16. Hydraulic Conductivity vs. Dynamic Head from the stochastic model run.

\section{Prediction Model}

In order to estimate sustainable yield, the pumping rate of the Bloomington well was steadily increased for each timeframe. After increasing the pumping rate of the Bloomington well for each step, a steady decrease in the head at that well was observed. The change in drawdown with each timeframe can be seen in Figure 17. The drawdown at each interval had a linear relationship with the pumping rate. The predictive model estimated a maximum discharge of $\sim 47,700 \mathrm{~m}^{3} / \mathrm{d}$ before the well went dry. This means that using this pumping rate would result I the aquifer becoming dry. The aquifer can become desaturated at a pumping rate of $\sim 31,800$ $\mathrm{m}^{3} / \mathrm{d}$. This desaturation occurs when the potentiometric surface meets the top of the St. Peter Aquifer. 


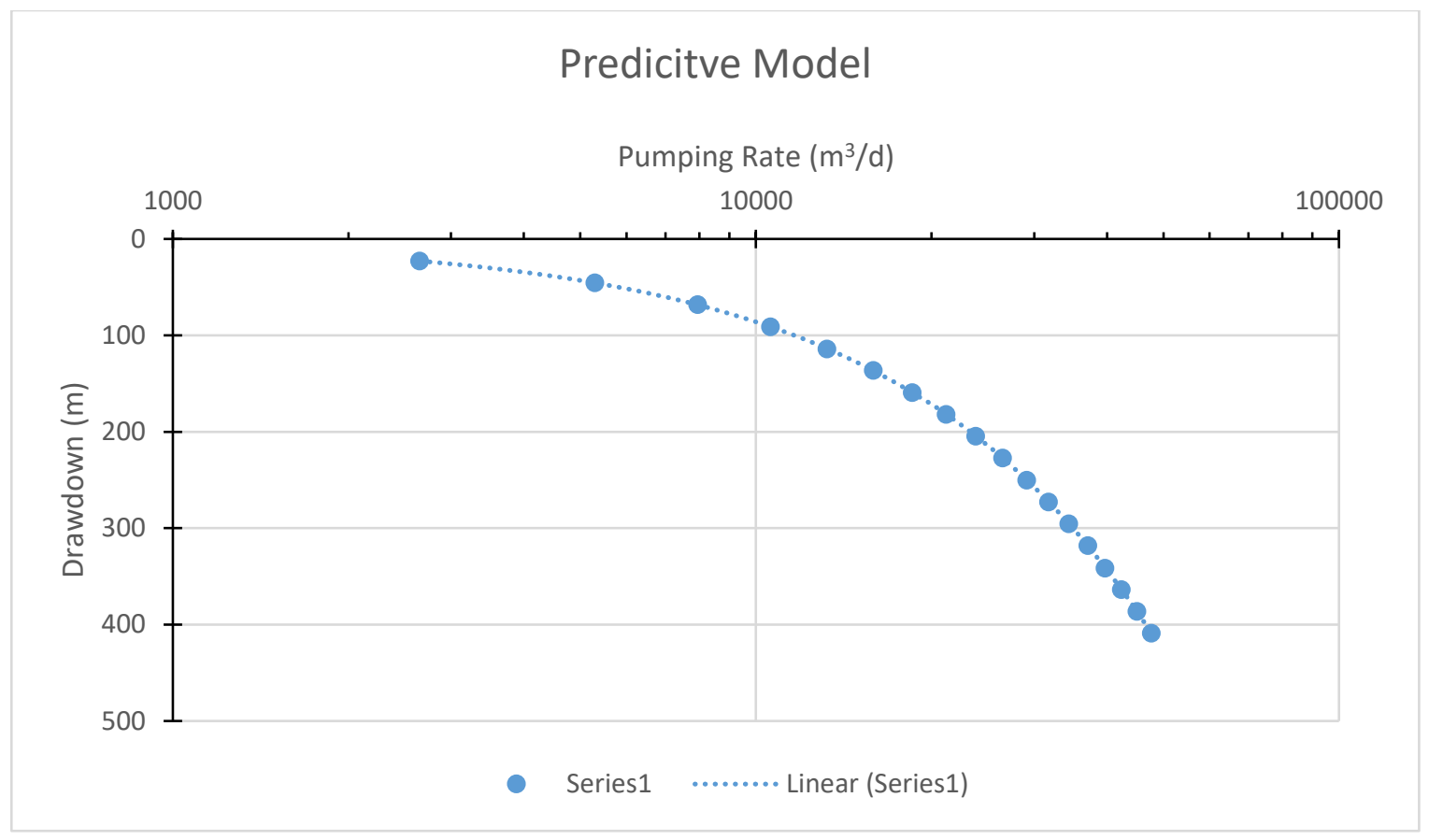

Figure 17. Predicted drawdown due to pumping based on the predictive model. 


\section{CHAPTER V: DISCUSSION}

\section{Calibration and Validation}

\section{Regional Model}

When calibrating the regional model, it was difficult to reduce the Mean Residual Error (MRE) lower than a MRE of -16.48. Residual head of each observation well varied greatly as seen in Table 10 and Figure 18. The large range in residual head values indicates water level is not static and varies throughout the study area. Head would even vary greatly in wells near each other. This variance in head means that the effect of pumping is local, meaning that distant pumping wells have no effect on the Bloomington wells.

When running the regional groundwater model, many observation wells showed an overestimation in head, meaning that computed heads were higher than head values observed in the field. The hypothesis for the overestimation in computed head is because our model is not as detailed as the IGWFM. Initially, the regional model only ran using the exact pumping rates for the year 2013 taken from the ISWS, but to better match the lower observed heads, pumping rates were increased (Table 3). The reason for calibrating the pumping wells is because of the inconsistency of pump datum from municipal wells. This lack of pumping datum is a limitation in an area like this where wells have been pumping for years and their effects have been studied. In order to account for the inconsistency of pumping datum, pumping from certain municipal wells was increased. The increase in the pumping rate decreased the computed head near observation wells that were overestimating, resulting in a lower RME and RMS.

The computed head from our regional model was plotted against the computed head as seen in Figure 18. The blue dashed line is the 1:1 correlation line that would be ideal in model calibration. The regional model has a MRE of $16.18 \mathrm{~m}$ and a RMS $46.8 \mathrm{~m}$ which compared to 
the IGWFM the model, did not perform as well. The IGWFM has a MRE of $-2.86 \mathrm{~m}$ and an RMS of $19.4 \mathrm{~m}$ for the transient model run. Statistics for the IGWFM for the 2013 year were a MRE of $3.99 \mathrm{~m}$ and a RMS of $18.1 \mathrm{~m}$, still outperforming the regional model. This comparison shows that it would be better to run a more complex model to study long term effects of pumping at a regional scale. The IGWFM had a total of 21 layers in their model.

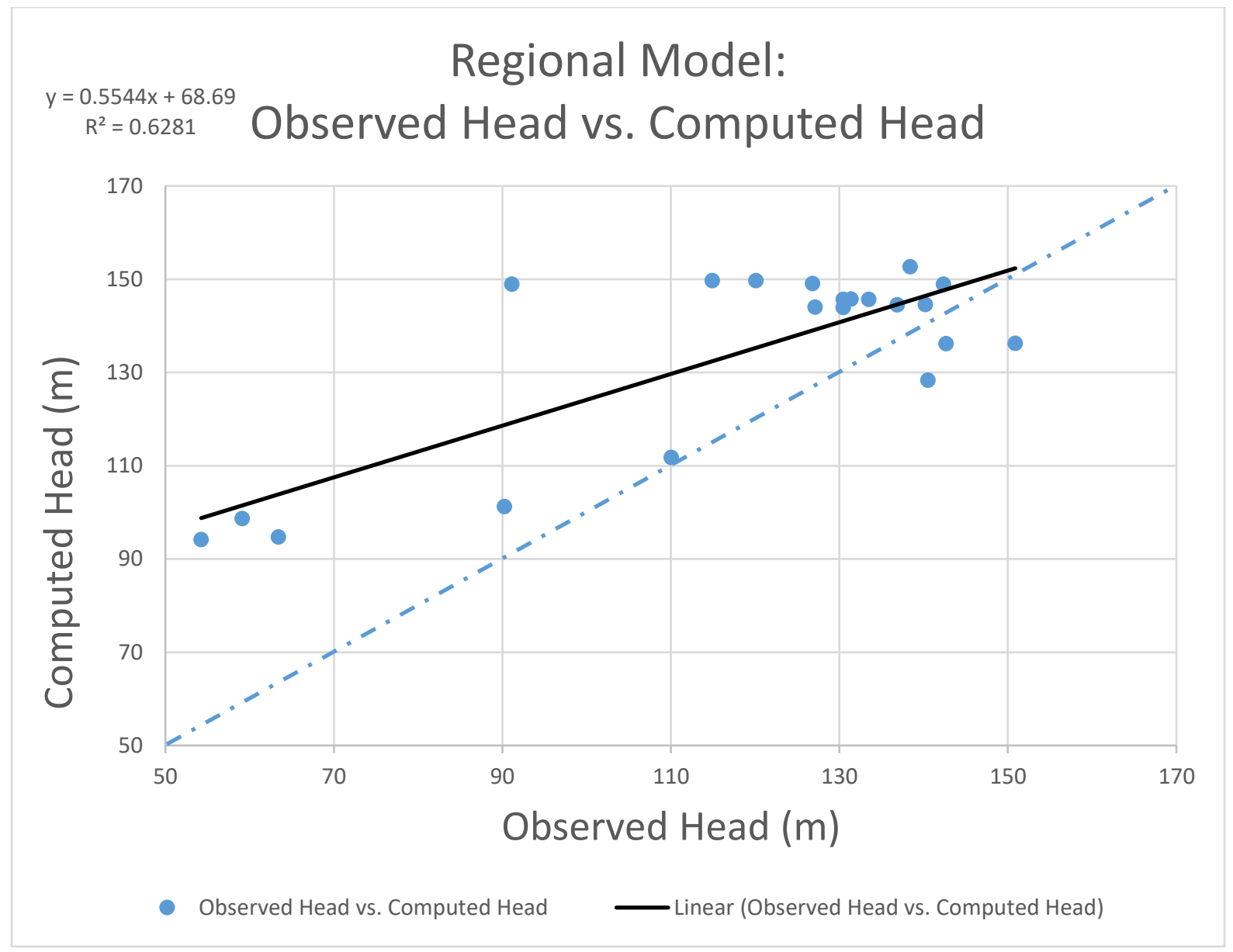

Figure 18. Observed Head vs. Computed Head of the regional model. Blue dashed line a 1:1 line

A contour map of head values throughout the regional model can be seen in Figure 18. The area in the northeast part of the regional model have the lowest head values. This is likely due to being near Aurora and Joliet, areas that have been pumping from the St. Peter Aquifer for decades. In addition, the no flow boundary was assigned to the north due to the presence of the 
Sandwich Fault Zone (Figure 3). The Sandwich Fault Zone exacerbates pumping effects due to a lack of lateral flow north the fault zone. Drawdown is highest in areas with consistent pumping and stay constant as you move towards central and southern part of the study area.

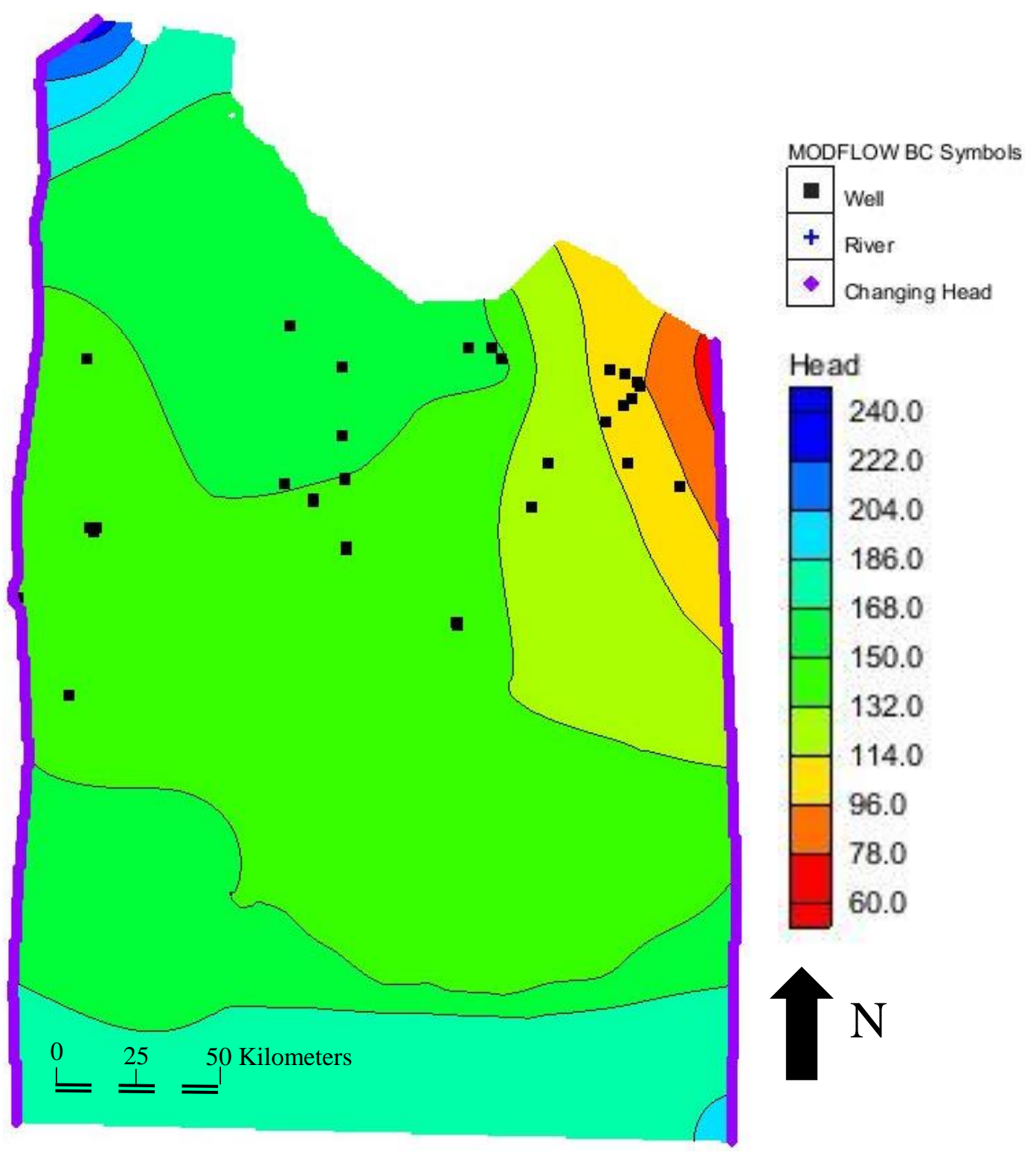

Figure 19. Contour map of regional model. Head values are in meters.

\section{Local Model}

Desaturation of the St. Peter aquifer due to over pumping in areas like Aurora and Joliet necessitated the need for a regional groundwater model. The hypothesis was that pumping in the 
regional groundwater system would have an effect on groundwater flow and head on the local scale. Interpolation of the regional model onto the local model showed that there was no impact of regional flow from wells at a local scale. This means that a change in pumping conditions in the regional model (i.e. Joliet and Aurora areas) has no impact on the drawdown on the Bloomington wells. Since regional pumping had no effect on drawdown in the Bloomington well, the parameters of the local model were calibrated independently of the regional model. The parameters calibrated were boundary conditions, pumping, and hydraulic conductivity.

\section{Boundaries}

We used specified head and no flow boundaries to delineate both our regional and local models. Initially we hypothesized the boundary conditions of the regional model could be interpolated from the regional model onto the local model. When interpolating the specified heads boundaries there was an underestimation of head in observation wells near the northeastern boundary. This indicated that the head interpolated from the regional mode underestimates head at a local scale. This is likely because in the regional model, the northeastern boundary is near the Joliet area which has a declining head due to over pumping. This indicated that the regional pumping conditions had no effect on head on wells far away on a local scale. The northeastern specified head boundary was increased in the local model and was based on the IGWFM. The increase in the specified head boundary from $115 \mathrm{~m}$ to $136 \mathrm{~m}$ led to an increase in observed head in wells near the boundary that were previously underestimating. These new specified head values were again taken from the IGWFM and can be found in Figure 9. The new specified head boundary conditions significantly reduced RME. The change in the boundary conditions led to a better fit local model compared to the regional model as seen in 
Figure 20. Thus, the local model was calibrated using pumping and hydraulic conductivity values.

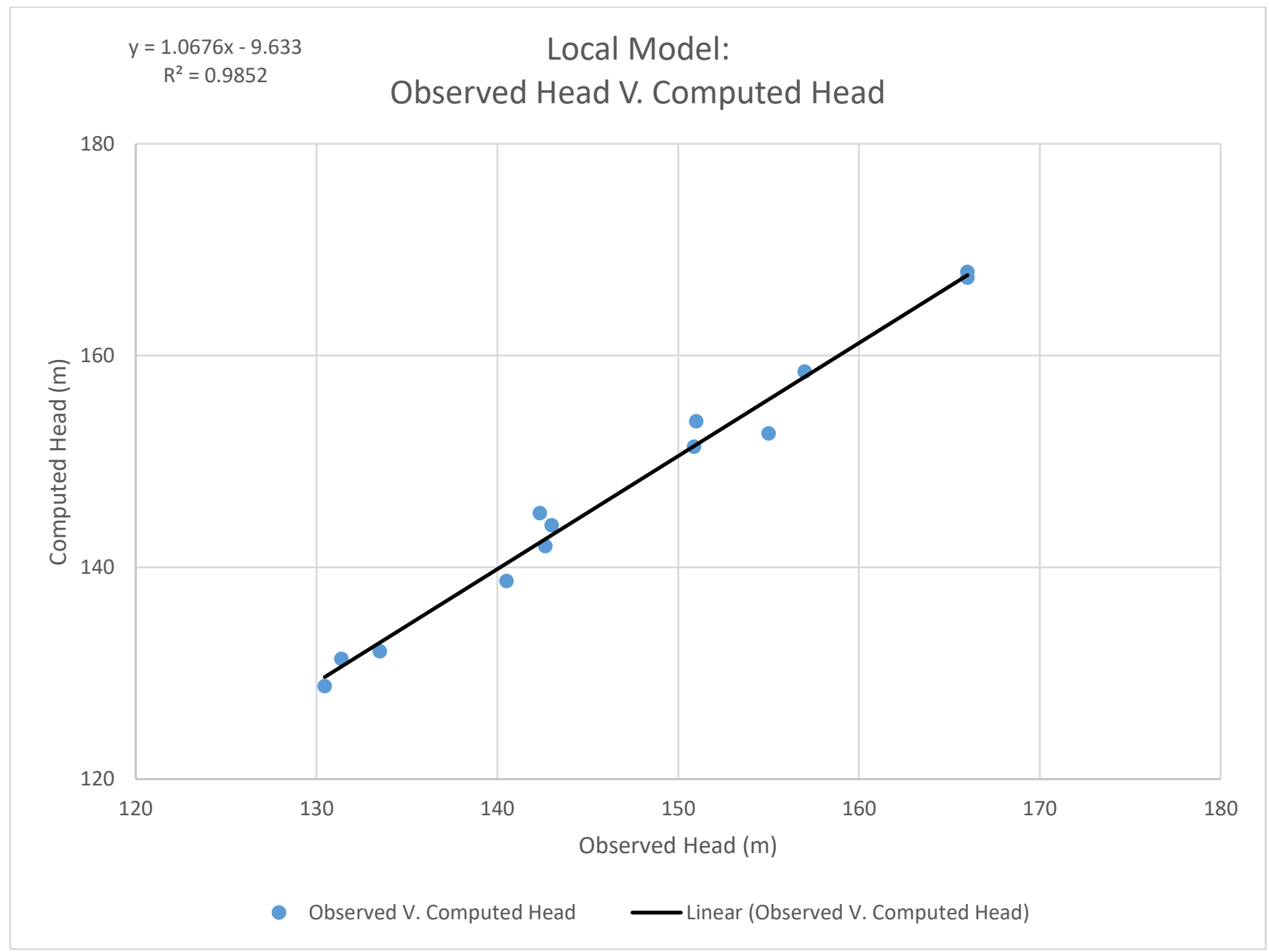

Figure 20. Observed Head vs. Computed Head of the local model.

A contour map of the local calibrated model can be found in Figure 21. Head values varied more on a local scale as seen around the Bloomington well. Like in the regional model, head values in the northeast were lower, but this was likely due to the boundary condition rather than the pumping in the area. 


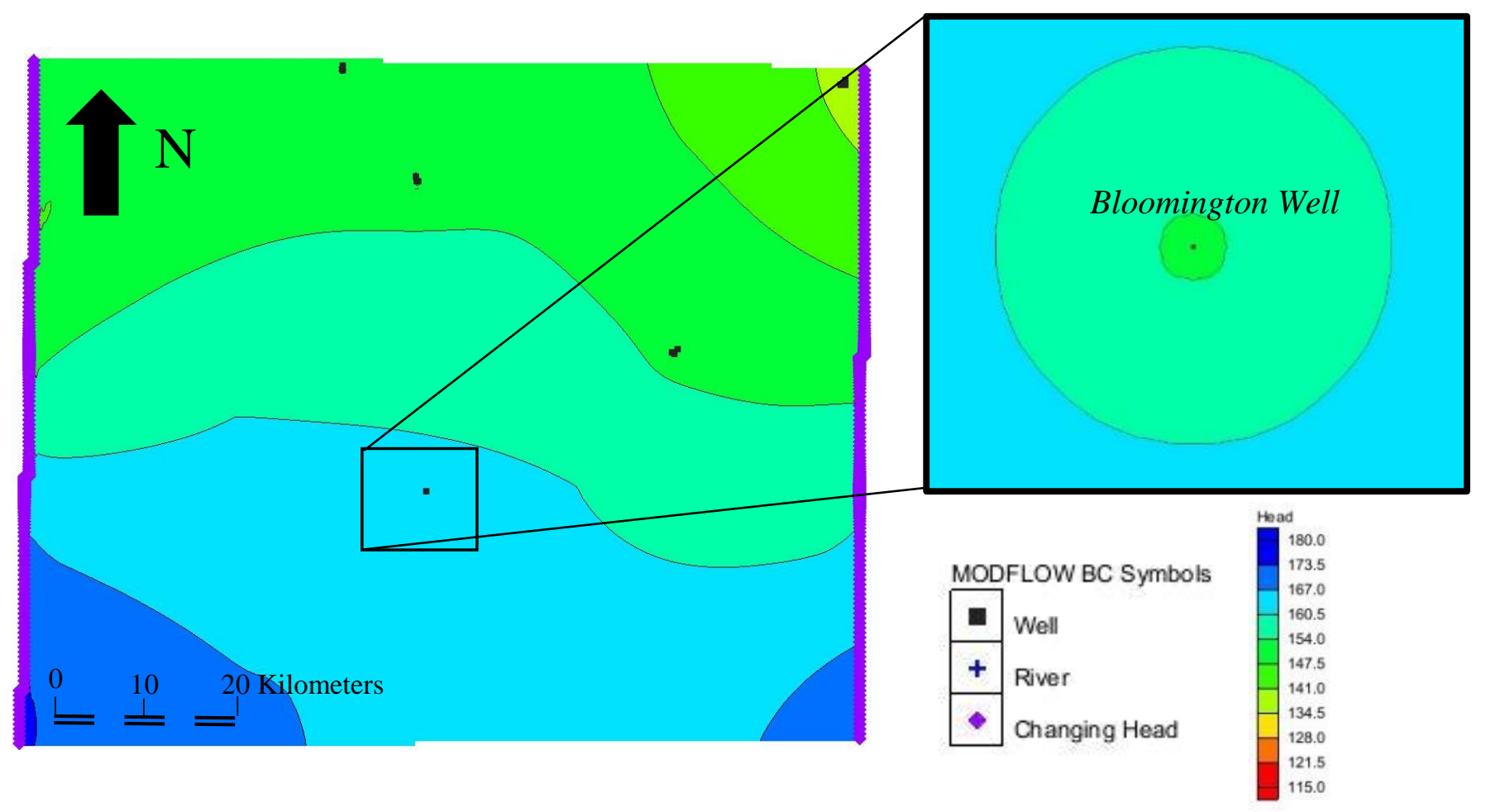

Figure 21. Contour map of local model. Head is in meters.

\section{Pumping}

This study used a steady state model to simulate the groundwater system because we assumed that there was little change in head over time. Using the initial pumping rates for 2013 resulted in an overestimate in head at many wells. In order to decrease head in a steady state model, the pumping rate $(\mathrm{Q})$ at various wells were increased. This increase in head was applied only to wells that have been pumping for years and were overestimating head. The increased pumping rate lowered the computed head and RME in many wells (table 3). Calibrating the pumping rate means the prolonged pumping had a bigger impact than initially hypothesized. Increasing the pumping rate to account for years of pumping created a pseudo-transient model, which takes into account the years of pumping, but the model still runs for a single time frame. It was also noted that wells closer to each other effect each other in the model. This occurred when 2 or more wells are located in the same grid frame in the model. The wells may have different 
observed head values and when calibrating Q of one well will drastically affect the computed head of the neighboring well.

\section{Hydraulic Conductivity}

In both models hydraulic conductivity $(\mathrm{K})$ proved to be the most sensitive parameter. Hydraulic conductivity was changed manually for both the local and regional model to help reduce MRE and RME throughout the study area. We based K values of each layer in the model from the IGWFM. Each layer had different K values throughout the layer and was divided into different zones (Figure 10). K for layer 2 was also calibrated based on the Bloomington Pump test.

$\mathrm{K}$ was calibrated to match the drawdown from the Bloomington pumping test observed by the ISWS. A static water level of $\sim 159 \mathrm{~m}$ was calculated at the Bloomington well before discharge $(\mathrm{Q})$ from the well was added. When a $\mathrm{Q}$ of $-1668 \mathrm{~m}^{3} / \mathrm{d}$ was added to the well, a head of $134.86 \mathrm{~m}$ was computed or resulting in a net drawdown of $24.14 \mathrm{~m}$. The Bloomington pumping test showed that a $\mathrm{Q}$ of $-1668 \mathrm{~m}^{3} / \mathrm{d}$ would only result in a net drawdown of $10 \mathrm{~m}$, so the hypothesis was that $\mathrm{K}$ was too low. The hypothesis is that there must be leakage from the overlying carbonate (Galena-Platteville formation), but $\mathrm{K}$ of the overlaying layer was too low to simulate leakage. $\mathrm{K}$ of Layer 1 was then increased from $\mathrm{K}_{\mathrm{x}}=0.000109728 \mathrm{~m} / \mathrm{d}$ and $\mathrm{K}_{\mathrm{y}}$ $=0.00001292 \mathrm{~m} / \mathrm{d}$ to $10 \mathrm{~m} / \mathrm{d}$ for $\mathrm{K}_{\mathrm{x}}$ and $\mathrm{K}_{\mathrm{y}}$ (table 2). This increase in $\mathrm{K}$ was only applied to the cells surrounding the Bloomington well in order to decrease the head error at the well. The increase in K simulated water leaking into the St. Peter Aquifer and decrease net drawdown. The net drawdown then decreased to $20 \mathrm{~m}$ which confirmed that the overlying layer has a bigger role in water flow in the system than initially hypothesized. The net drawdown was still overestimating by $\sim 10 \mathrm{~m}$, so the next model parameter to change was the GR parameters. 


\section{Grid Refinement (GR)}

Various grid refinement sizes were tested to find the optimum grid size that would be small enough to show changes in head at a local scale, but not so small that it drastically effects the drawdown in the base cell. We hypothesized the base cell size of $5 \mathrm{~m}$ was too small, leading the overestimation in net drawdown. The final GR parameters for the model were a base cell size of 20 meters, bias of $10 \%$, and a maximum cell size of $500 \mathrm{~m}$. The hydraulic conductivity parameters calibrated in the previous section are found in Table 2. This combination of parameters saw a net drawdown of $\sim 12 \mathrm{~m}$ in the base cell, with a net drawdown of $\sim 10 \mathrm{~m}$ in the 3x3 matrix surrounding the well. Since we are using GR to better understand the groundwater system around Bloomington we don't want to increase the base cell size too much. This is why an average of the $3 \mathrm{X} 3$ matrix surrounding the well was taken, in order to assess the influence of pumping in the area around the well (Figure 14). A larger base cell size would counteract the benefits of GR.

By applying the GR method to the Chenoa allowed for neighboring wells in that area to be assigned to different grid cells. Before applying the GR method, neighboring wells in this area were in the same grid cell, making calibration difficult. If you have more than one pumping well per grid cell the pumping from each well drastically changes head in both corresponding observation wells showing again that pumping only affects the water table on a local scale.

\section{Parameter Sensitivity and Uncertainty Analysis}

From sensitivity analysis, hydraulic conductivity $(\mathrm{K})$ was determined to be the most sensitive parameter. As a result parameter uncertainty in the model, if occurs, probably expected from the uncertainty of $\mathrm{K}$. Therefore, a stochastic model was simulated using randomly selected hydraulic conductivity values with + or $-20 \%$ bound from calibrated K value with a total run of 
50 simulations. The results of the 50 simulations can be found in Figure 16. K values less than $0.5 \mathrm{~m} / \mathrm{d}$ resulted in exponentially greater changes in head for every decrease in $\mathrm{K}$. This large decrease in head shows that the aquifer is very sensitive to changes in K. Since the St. Peter is buried at a large depth in this area, a lower than expected $\mathrm{K}$ was to be expected. Values of $\mathrm{K}$ less than $0.5 \mathrm{~m} / \mathrm{d}$ is very unlikely for a quartz arenite like the St. Peter Sandstone and should not be a limiting factor when the Bloomington Well begins pumping.

The stochastic model also saw that a large increase in $\mathrm{K}$ will not change the dynamic head much with the amount of pumping from the Bloomington pumping test. This is because the flow of water is so fast, water will replenish the water pump out by the Bloomington pumping well. The results showed that a hydraulic conductivity of less than $0.5 \mathrm{~m} / \mathrm{d}$ resulted in exponential decreases in head as seen in Figure 16.

In the uncertainty analysis different recharge rates were also tested to assess its effect on drawdown. The range of recharge values used were so small and insignificant that there was negligible changes in dynamic head due to changes in recharge.

The model showed to be sensitive to changing parameters, specifically changes in hydraulic conductivity as seen in Figure 16. The trend seen from the Bloomington pumping test (Figure 22). The St. Peter Aquifer follows a typical Hantush and Jacob drawdown curve in response to continuous pumping. (Hantush and Jacobs, 1955). 
Figure 22. Aquifer response to the Bloomington pumping test in meters.

\section{Prediction Model}

Our second research question was: does the addition of two municipal wells by Bloomington, IL into the St. Peter aquifer satisfy increased projected water demand and future water quality problems without exceeding sustainable yield of the aquifer? Sustainable yield we defined as, the amount of water that can be withdrawn from an aquifer without producing an undesirable result. In our case, an undesirable result is desaturation of the aquifer. To estimate sustainable yield of the aquifer we ran a predictive model.

Our predictive model took a pseudo-transient modeling approach as opposed to a real transient modeling approach. In a real transient model, pumping is applied for period of time at 
specified intervals or timeframes. At each timeframe the model takes into account pumping and head from the previously run timeframe. In our pseudo-transient modeling approach, the pumping rate was increased manually at each timeframe and did not take into account the change in head from the previous timeframe. This approach was taken as pumping from the well has not begun and the well is not expected to be running year-round. This approach is more of an estimate to quantify the total amount of water that can be taken from the Aquifer before it goes dry.

The pumping rate was increased for each timeframe until the cell containing the Bloomington well was dry. A pumping rate of $2649.8 \mathrm{~m}^{3} / \mathrm{d}$ based off of the city's Water Supply plan. This was an estimate of how much water the city might pump in the future. The pumping rate was increased based on the projected demand from equation 4 . There was a predicable relationship with the amount of water pumped from the aquifer and the drawdown as seen in Figure 17. This trend makes sense because the aquifer is homogenous and isotropic. These aquifer parameters allow for water to flow equally in towards the well from all directions.

The predictive model estimated a maximum discharge of $\sim 47,700 \mathrm{~m}^{3}$ before the well went dry. The aquifer become unsaturated $\sim 31,800 \mathrm{~m}^{3}$. The pumping rate used to predict this assumed that the St. Peter would account for $5 \%$ of the city's water needs in the future. With this high pumping rate this can result in low sustainable yield. This predictive model shows that pumping from the St. Peter Aquifer will not satisfy increases in projected water demand without exceeding sustainable yield. The issue with this predictive model is that pumping rate is unrealistic for the pumping capacity of any well.

Pumping from the St. Peter Aquifer would be inherently unsustainable due to the lack of recharge into the aquifer. The scenario run in this model was just one of many and was an 
estimate of Bloomington's future water demands. Though the predictive model shows that the aquifer can be depleted after applying a certain pumping rate, the pumping rate used in the predictive model is unrealistic. The frequency and amount of water pumped from the aquifer will still determine the sustainable yield of the well. The predictive model shows instead that pumping from the St. Peter is not a water quantity issue.

\section{Model Gaps and Uncertainties}

The model in this study lumped the geologic layers overlying the St. Peter into one aquitard (Layer 1) assuming that insignificant amounts of water were reaching the St. Peter Aquifer from the surface. Initially $\mathrm{K}$ of the overlying layer was very low in order to simulate Layer 1 as an aquitard. Calibration of the Bloomington Pumping test showed that an increase in $\mathrm{K}$ in Layer 1 in some areas led to higher model performance. Calibration of Layer 1 showed that the overlying material has a bigger role than initially presumed, therefore Layer 1 is not entirely an aquitard as initially hypothesized. This could be due to missing bedrock, buried valleys, with possible leakage from the overlying Glena-Platteville Carbonate. Future models looking into the Cambrian-Ordovician groundwater system should differentiate the overlying layers into their respective hydrogeologic layers.

The other uncertainty in this study is the steady state/pseudo-transient approach taken to model the system. This resulted in a higher RME and MRE compared to the IGWFM which took a real transient modeling approach. The large mean residual error of $-16.8 \mathrm{~m}$ and the large amount of time to calibrate the regional model meant that the groundwater system for the regional model was over simplified. The IGWFM was a better fit for regional flow in the system likely because their approach to make a multi layered model made a better fit on a regional scale. 
The last uncertainty in this model is the cell size. As stated previously, you want to have pumping wells in separate grid cells for easier calibration. Finding the right cell size affects calibration and changes in head. 


\section{CHAPTER VI: CONCLUSION}

As populations continues to grow and climate change makes precipitation events less predictable, groundwater becomes an increasingly important freshwater resource. Groundwater modeling has become a vital tool in protecting groundwater resources. The model in this study aimed at estimating sustainable yield. The groundwater model was built in GMS 10.3 using a variety of data. The groundwater models were calibrated using observation well and pump test datum. Once the model was calibrated, a predictive model was run based of predicted water demand for the city of Bloomington. Lastly, model parameter uncertainty was assessed using a stochastic modeling approach. The following major conclusions are drawn from this study:

- As the St. Peter increases in depth, hydraulic conductivity plays a bigger role in the sustainability of the aquifer

- Based on the stochastic analysis result, with a reasonable $(75 \%)$ parameter uncertainty for the hydraulic conductivity (low K, high K), the predicted uncertainty in the drawdown is no more than $7.5 \%$,

- Sensitivity test analysis result indicated using the current 5\% demand of the City of Bloomington and with acceptable range of the K values for St. Peter, the maximum drawn predicted would be $\sim 47,700 \mathrm{~m}^{3}$,

- A pumping rate of $2648.8 \mathrm{~m}^{3} / \mathrm{y}$, is unrealistic pumping capacity of a pumping well, meaning that the city of Bloomington can pump unabated from the St. Peter without having to worry about water quantity issues,

- The Sandwich Zone is acting as a no flow boundary in the regional model leading to larger drops in head in wells near the boundary, 
- The effects of pumping are localized with pumping from the larger regional model having no effect on distant wells,

- There is more interaction between the St. Peter Aquifer and the overlying units than initially hypothesized,

The predictive model took a pseudo-transient approach and saw a steady decline in head as pumping increased. Pumping from the St. Peter is not sustainable is more a mining venture. Therefore, it is in the best interest of the city of Bloomington to not rely heavily on water from the St. Peter as a long term solution. 


\section{REFERENCES}

Abrams, D.B, Hadley, D.R, Mannix, D.H, Roadcap, G.S, Meyer, S.C, Hlinka, K.J, Rennels, K.,Bradbury, K.R, Chase, P.M, \& Krause, J.J., 2015, Changing groundwater Levels in the sandstone Aquifers of Northern Illinois and Southern Wisconsin: Impacts on Available Water Supply. Illinois State Water Survey, Champaign, IL

Anderson, M.P., Woessner, W.W., Hunt, R.J., 2015, Applied Groundwater ModelingSimulation of flow and advective transport (2nd Edition): San Diego, Academic Press Inc., $564 \mathrm{p}$.

Aquaveo, 2018, XMS Wiki: https://www.xmswiki.com/wiki/GMS:Feature_Objects (accessed October 2018)

Bhowmik, N.G., and Schicht, R.J, 1980, Bank Erosion of the Illinois River: Illinois State Water Survey, Report of Investigation 92, p. 1-52

Bryant, T. P., and Meyer, S.C., 2013, Water Withdrawals and Use in Illinois, 2010: Illinois State Water Survey Contract Report 2013-04

Church, J.A., Clark, P.U., Cazenave, A., Gregory, J.M., Jevrejeva, S., Levermann, A., Merrifield,M.A., Milne, G.A., Nerem, R.S., Nunn, P.D., Payne, A.J., Pfeffer,W.T., Stammer, D.and Unnikrishnan, A.S., 2013,Climate Change 2013: The Physical Science Basis. Contribution of Working Group I to the Fifth Assessment Report of the Intergovernmental Panel on Climate Change, Cambridge University Press, Cambridge United Kingdom and New York, NY USA, 1137-1216 p., doi: 10.1017/ CBO9781107415324.026.

Custodio, E., 2002, Aquifer overexploitation: what does it mean?: Hydrogeology Journal, v. 10, no. 2, p. 254-277. 
Davis, J. G., 2012, St. Peter Sandstone Mineral Resource Evaluation, Missouri, USA | AZGS Document Repository: Arizona Geologic Survey, Special Report 9, p. 1-7.

Fishman, R. M., Siegfried, T., Raj, P., Modi, V., Lall, U., 2018, Over-extraction from shallow bedrock versus deep alluvial aquifers: Reliability versus sustainability considerations for India's groundwater irrigation: Water Resources Research, v. 47, no. 6.

Fox, M. A., Nachman, K. E., Anderson, B., Lam, J., and Resnick, B., 2016, Meeting the public health challenge of protecting private wells: Proceedings and recommendations from an expert panel workshop: Science of the Total Environment, v. 554-555, p. 113-118.

Freeze, R. A. and Cherry, J.A., 1979, Groundwater: Prentice Hall, Englewood Cliffs, NJ., 604 p. Hashemi, H., Uvo, C.B., and Berndtsson, R., 2015, Coupled modeling approach to assess climate change impacts on groundwater recharge and adaptation in arid areas: Hydrology and Earth System Sciences, v. 19, no. 10, p. 4165-4181.

Healy, C. R. a. H., Kenneth J., 2012, Water Withdrawals and Use in Illinois, 2012: Illinois State Water Survey: Prairie Research Institute

Honings, J.P., 2018, Modeling Climate Change impacts on Water Balance Coponents of the Mackinaw River Watershed, Central Illinois [Masters Thesis]: Illinois State University, $69 \mathrm{p}$.

Hunt, R.J., Doherty, J., amd Tonkin, M.J., 2007, Groundwater: Are Models Too Simple? Arguments for Increased Parameterization, v. 45, p. 254-262, doi: 10.1111/j.1745 6584.2007.00316.x

Kalf, F. P., and Donald, R. W., 2005, Applicability and methodology of determining sustainable yield in groundwater systems: Hydrogeology journal, v. 13, no. 1, p. 295-312. doi: $10.1007 / \mathrm{s} 10040-004-0401-\mathrm{x}$ 
Keir, G., Bulvic, N., and McIntyre, N.n, 2019, Groundwater: Stochastic Modeling of Groundwater Extractions over a Data-Sparse Region of Australia, v. 57, p.97-109, doi: $10.1111 /$ gwat. 12658

Kolata, D.R., and Nimz, C. K., 2010, Geology of Illinois: Illinois State Geologic Survey, p.325 336

Konstantinou, A., Wirth, K.R., Vervoot, J.D., Malone, D.H., Davidson, C., and Craddock, J.P., 2014, Provenance of Quartz Arenites of the Early Paleozoic Midcontinent Region, USA: The Journal of Geology, no. 2, p. 201-216.

Kresic, N. and Mikszewski, 2012, Hydrogeological Conceptual Site Models: Data Analysis and Visualization, $600 \mathrm{p}$.

Labuz, J., 2002, Field and laboratory testing of St. Peter sandstone: Journal of Geotechnical and Geoenvironmental Engineering, v. 128, no. 5, p.372-380.

Lavaire, T., Gentry, L. E., David, M. B., and Cooke, R. A., 2017, Fate of water and nitrate using drainage water management on tile systems in east-central Illinois: Agricultural Water Management, v. 191, p. 218-228.

Medina, C.R. Rupp, J.A., and Barnes, D.A, 2011, International journal of Greenhouse Gas Control: Effects of reduction in porosity and permeability with depth on storage capacity and injectivity in deep saline aquifers: A case study from Mount Simon Sandstone aquifer, v. 5, p. 146-156, doi: 10.1016/j.ijggc.2010.03.001

Mehl, S., and Hill, M. C., 2002, Evaluation of a local grid refinement method for steady-state block-centered finite-difference groundwater models: Developments in Water Science, v. 47, p. 367-374. 
Mehl, S., Hill, M. C., and Leake, S. A., 2006, Comparison of Local Grid Refinement Methods for MODFLOW: Ground Water, v. 44, no. 6, p. 792-796.

Meyer, S.C., Roadcap, G.S., Lin, Y., 2009, kane County Water Resources Investigations;

Simulation of Groundwater Flow in Kane County and Northeastern Illinois: Illinois state Water Survey

Pandey, V. and Kazama, F., 2011, Nepal, Environmental Earth Sciences: Hydrogeologic characteristics of groundwater aquifers in Lathmandu Valley, v. 62, p. 1723-1732, doi: $10.1007 / \mathrm{s} 12665-010-0667-3$.

Panno, S. V., Askari, Z., Kelly, W. R., Parris, T. M., and Hackley, K. C., 2017, Recharge and Groundwater Flow Within an Intracratonic Basin, Midwestern United States: Ground Water, v. 56, no. 1, p. 32-45.

Peel, M.C., Finlayson, B.L., and McMahon, T.A., Updates world map of the Köppen-Geiger climate classification, Climate Research, v. 59, p.1-13, doi: 10.3354/cr01204

Pitman, J. K., Goldhaber, M. B., and Spöetl, C., 1997a, Regional diagenetic patterns in the St. Peter Sandstone : implications for brine migration in the Illinois Basin, Washington : U.S. G.P.O. ; Denver, CO : For sale by U.S. Geologic Survey, Information Services, 1997., Evolution of sedimentary basins--Illinois Basin: A.

Psarropoulou, E.T. and Karatzas, G.P., 2012, Civil Engineering and Environmental Systems: Transient groundwater modelling with spatio-temporally variable fluxes in a complex aquifer system: new approach in defining boundary conditions for a transient flow model, v. 29, no. 1, p. 1-21, doi: 10.1080/10286608.2011.637622 
Roadcap, G., Knapp, H.V., Wehrmann, H.A., and Larson, D.R. 2011. Meeting East Central Illinois Water Needs to 2050: Potential Impacts on the Mahomet Aquifer and Surface Reservoirs, Illinois State Water Survey Contract Report, Champaign, IL.

Romano, E., and Preziosi, E., 2010, The Sustainable Pumping Rate Concept: Lessons from a Case Study in Central Italy: Groundwater, v. 48, no. 2, p. 217-226, doi: 10.1111/j.1745 6584.2009.00628.x

Sahoo, S., and Jha, M., 2017, Hydrogeology Journal: Numerical groundwater-flow modeling to evaluate potential effects of pumping and recharge: implications for sustainable groundwater management in the Mahanadi delta region, India, v. 25, no. 8, p. 2489-2511, doi: 10.1007/s10040-017-1610-4.

Shaver, R. H., and Burger, A. M., Gates, G.R, Gray, H.H, Hutchison, H.C, Keller, S.J, Patton, J.B, Rexroad, C.B, Smith, N.M, Wayne, W.J, and Wier, C.E, 1970, Compendium of Rock Unit Stratigraphy in Indiana.

Siarkos, I., Latinopoulos, P., 2012, Delineation of wellhead protection zones for the cpntrol of point pollution source in the aquifer of N. Moudania, Greece: European Water, v. 40, p. 3-17

Theil, G. A., 1935, Sedimentary and petrographic analysis of the St. Peter sandstone: GSA Bulletin, v. 46, no. 4, p. 559-614.

United Nations, 2016, The United Nations World Water Development Report 2016, United Nations World Water Assessment Programme.

United States Geological Survey, 2018, MODLOW and Related Programs: https://www.usgs.gov/mission-areas/water-resources/science/modflow-and-related programs?qt-science_center_objects=0\#qt-science_center_objects (accessed June 2018) 
Walker, D.D. 2009. Kane County Water Resources Investigations: Simulation of Groundwater Flow in Kane County and Northeastern Illinois. Illinois State Water Survey Contract Report, 2009-07.

Wilson, S.D, Rennels. K.L, \& Roadcap, G.S. 2013. A Water Inventory Assess Potential Conflicts from Development of a Well Field in Selected Areas of McLean, Tazewell, and Woodford Counties, Illinois. Illinois State Water Survey Contract Report. 2013-03.

Worthington, V. E., Burt, O. R., and Brustkern, R. L., 1985, Optimal management of a confined groundwater system: Journal of Environmental Economics and Management, v. 12, p. 229-245. 
APPENDIX: STOCHASIC MODELING

Table A-1. Stochastic model parameters. Hydraulic Conductivity values and recharge values used in Stochastic model.

\begin{tabular}{|l|l|l|l|l|}
\hline Name & HK_100 & HK_200 & HK_300 & RCH_400 \\
\hline Std. Deviation & 1.95 & 0.99 & 1.95 & $2.08 \mathrm{E}-06$ \\
\hline Mean Value & 0.223381 & 0.014727 & 1.038448 & $2.10 \mathrm{E}-07$ \\
\hline Run 1 & 0.992697 & 0.098204 & 2.339631 & $2.10 \mathrm{E}-07$ \\
\hline Run 2 & 2.995521 & 0.058713 & 3.550803 & $2.10 \mathrm{E}-07$ \\
\hline Run 3 & 0.699576 & 0.025861 & 4.205323 & $2.10 \mathrm{E}-07$ \\
\hline Run 4 & 0.969968 & 0.012546 & 2.695233 & $2.10 \mathrm{E}-07$ \\
\hline Run 5 & 1.362589 & 0.674977 & 0.412533 & $2.10 \mathrm{E}-07$ \\
\hline Run 6 & 0.347954 & 0.017326 & 4.599582 & $2.10 \mathrm{E}-07$ \\
\hline Run 7 & 1.36041 & 0.178124 & 0.201585 & $2.10 \mathrm{E}-07$ \\
\hline Run 8 & 0.521443 & 0.096855 & 0.97069 & $2.10 \mathrm{E}-07$ \\
\hline Run 9 & 1.01781 & 0.022093 & 0.362269 & $2.10 \mathrm{E}-07$ \\
\hline Run 10 & 0.879575 & 0.079032 & 0.245783 & $2.10 \mathrm{E}-07$ \\
\hline Run 11 & 0.791781 & 0.209896 & 0.123087 & $2.10 \mathrm{E}-07$ \\
\hline Run 12 & 0.205287 & 0.076029 & 0.230766 & $2.10 \mathrm{E}-07$ \\
\hline Run 13 & 1.39003 & 0.016875 & 0.284012 & $2.10 \mathrm{E}-07$ \\
\hline Run 14 & 0.115672 & 0.4654 & 1.097166 & $2.10 \mathrm{E}-07$ \\
\hline Run 15 & 0.773072 & 0.036731 & 0.393912 & $2.10 \mathrm{E}-07$ \\
\hline Run 16 & 0.240801 & 0.149579 & 0.924558 & $2.10 \mathrm{E}-07$ \\
\hline Run 17 & 0.200687 & 0.025361 & 0.71171 & $2.10 \mathrm{E}-07$ \\
\hline Run 18 & 1.986505 & 0.157904 & 0.483623 & $2.10 \mathrm{E}-07$ \\
\hline Run 19 & 3.38561 & 0.011032 & 1.556161 & $2.10 \mathrm{E}-07$ \\
\hline Run 20 & 4.664561 & 0.064658 & 0.354551 & $2.10 \mathrm{E}-07$ \\
\hline Run 21 & 4.141778 & 0.093061 & 2.15272 & $2.10 \mathrm{E}-07$ \\
\hline Run 22 & 0.546946 & 0.228862 & 2.20535 & $2.10 \mathrm{E}-07$ \\
\hline Run 23 & 0.1879 & 0.09429 & 0.212884 & $2.10 \mathrm{E}-07$ \\
\hline Run 24 & 0.181878 & 0.061754 & 0.276443 & $2.10 \mathrm{E}-07$ \\
\hline Run 25 & 0.406971 & 0.18808 & 0.615252 & $2.10 \mathrm{E}-07$ \\
\hline Run 26 & 1.5368 & 0.158934 & 1.065088 & $2.10 \mathrm{E}-07$ \\
\hline Run 27 & 0.399029 & 0.030834 & 0.124477 & $2.10 \mathrm{E}-07$ \\
\hline Run 28 & 1.714823 & 0.025388 & 0.10694 & $2.10 \mathrm{E}-07$ \\
\hline Run 29 & 2.309498 & 0.012479 & 0.197822 & $2.10 \mathrm{E}-07$ \\
\hline Run 30 & 0.240922 & 0.020962 & 1.829225 & $2.10 \mathrm{E}-07$ \\
\hline Run 31 & 0.23076 & 0.390031 & 2.170063 & $2.10 \mathrm{E}-07$ \\
\hline Run 32 & 0.660668 & 0.12485 & 4.399394 & $2.10 \mathrm{E}-07$ \\
\hline Run 33 & 1.929507 & 0.029586 & 0.985889 & $2.10 \mathrm{E}-07$ \\
\hline Run 34 & 2.091083 & 0.204185 & 0.591526 & $2.10 \mathrm{E}-07$ \\
\hline Run 35 & 0.256425 & 0.480204 & 0.397089 & $2.10 \mathrm{E}-07$ \\
\hline & & & & \\
\hline
\end{tabular}




\begin{tabular}{|l|l|l|l|l|}
\hline Run 36 & 0.138198 & 0.228784 & 0.515774 & $2.10 \mathrm{E}-07$ \\
\hline Run 37 & 3.759031 & 0.015221 & 0.179411 & $2.10 \mathrm{E}-07$ \\
\hline Run 38 & 0.546409 & 0.228748 & 2.70171 & $2.10 \mathrm{E}-07$ \\
\hline Run 39 & 3.496546 & 0.066044 & 2.014337 & $2.10 \mathrm{E}-07$ \\
\hline Run 40 & 1.566202 & 0.129294 & 4.12829 & $2.10 \mathrm{E}-07$ \\
\hline Run 41 & 0.23213 & 0.028731 & 2.470759 & $2.10 \mathrm{E}-07$ \\
\hline Run 42 & 2.250482 & 0.026736 & 1.686615 & $2.10 \mathrm{E}-07$ \\
\hline Run 43 & 0.208396 & 0.018166 & 0.634031 & $2.10 \mathrm{E}-07$ \\
\hline Run 44 & 4.239764 & 0.077512 & 0.881437 & $2.10 \mathrm{E}-07$ \\
\hline Run 45 & 0.128403 & 0.100459 & 0.180862 & $2.10 \mathrm{E}-07$ \\
\hline Run 46 & 0.431034 & 0.828831 & 0.961223 & $2.10 \mathrm{E}-07$ \\
\hline Run 47 & 0.683888 & 0.010132 & 2.032237 & $2.10 \mathrm{E}-07$ \\
\hline Run 48 & 3.118155 & 0.029997 & 0.957324 & $2.10 \mathrm{E}-07$ \\
\hline Run 49 & 0.857408 & 0.115702 & 1.684014 & $2.10 \mathrm{E}-07$ \\
\hline Run 50 & 0.223381 & 0.014727 & 1.038448 & $2.10 \mathrm{E}-07$ \\
\hline
\end{tabular}

